\title{
Millennial-scale variations in sedimentary oxygenation in the western subtropical North Pacific and its links to North Atlantic climate
}

\author{
Jianjun Zou ${ }^{1,2}$, Xuefa Shi ${ }^{1,2}$, Aimei Zhu ${ }^{1}$, Selvaraj Kandasamy ${ }^{3}$, Xun Gong ${ }^{4}$, Lester Lembke-Jene ${ }^{4}$, Min-Te Chen ${ }^{5}$, \\ Yonghua Wu ${ }^{1,2}$, Shulan Ge ${ }^{1,2}$, Yanguang Liu ${ }^{1,2}$, Xinru Xue ${ }^{1}$, Gerrit Lohmann ${ }^{4}$, and Ralf Tiedemann ${ }^{4}$ \\ ${ }^{1}$ Key Laboratory of Marine Sedimentology and Environmental Geology, First Institute of Oceanography, \\ MNR, Qingdao 266061, China \\ ${ }^{2}$ Laboratory for Marine Geology, Qingdao National Laboratory for Marine Science and Technology, Qingdao, 266061, China \\ ${ }^{3}$ Department of Geological Oceanography and State Key Laboratory of Marine Environmental Science, \\ Xiamen University, Xiamen 361102, China \\ ${ }^{4}$ Alfred-Wegener-Institut Helmholtz-Zentrum für Polar- und Meeresforschung, Am Handelshafen 12, \\ 27570 Bremerhaven, Germany \\ ${ }^{5}$ Institute of Earth Sciences \& Center of Excellence for the Oceans \& Center of Excellence for Ocean Engineering, National \\ Taiwan Ocean University, Keelung 20224, Taiwan
}

Correspondence: Jianjun Zou (zoujianjun@fio.org.cn) and Xuefa Shi (xfshi@fio.org.cn)

Received: 8 June 2019 - Discussion started: 20 June 2019

Revised: 13 November 2019 - Accepted: 8 January 2020 - Published: 20 February 2020

\begin{abstract}
The deep-ocean carbon cycle, especially carbon sequestration and outgassing, is one of the mechanisms to explain variations in atmospheric $\mathrm{CO}_{2}$ concentrations on millennial and orbital timescales. However, the potential role of subtropical North Pacific subsurface waters in modulating atmospheric $\mathrm{CO}_{2}$ levels on millennial timescales is poorly constrained. An increase in the respired $\mathrm{CO}_{2}$ concentration in the glacial deep-ocean due to biological pump generally corresponds to deoxygenation in the ocean interior. This link thus offers a chance to study oceanic ventilation and coeval export productivity based on redox-controlled sedimentary geochemical parameters. Here, we investigate a suite of geochemical proxies in a sediment core from the Okinawa Trough to understand sedimentary oxygenation variations in the subtropical North Pacific over the last 50000 years (50 ka). Our results suggest that enhanced mid-depth western subtropical North Pacific (WSTNP) sedimentary oxygenation occurred during cold intervals and after $8.5 \mathrm{ka}$, while oxygenation decreased during the Bölling-Alleröd (B/A) and Preboreal. The enhanced oxygenation during cold spells is linked to the North Pacific Intermediate Water (NPIW), while interglacial increase after $8.5 \mathrm{ka}$ is linked to an intensification of the Kuroshio Current due to strengthened northeast trade
\end{abstract}

winds over the tropics. The enhanced formation of the NPIW during Heinrich Stadial 1 (HS1) was likely driven by the perturbation of sea ice formation and sea surface salinity oscillations in the high-latitude North Pacific. The diminished sedimentary oxygenation during the $\mathrm{B} / \mathrm{A}$ due to a decreased NPIW formation and enhanced export production, indicates an expansion of the oxygen minimum zone in the North Pacific and enhanced $\mathrm{CO}_{2}$ sequestration at mid-depth waters, along with the termination of atmospheric $\mathrm{CO}_{2}$ concentration increase. We attribute the millennial-scale changes to an intensified NPIW and enhanced abyss flushing during deglacial cold and warm intervals, respectively, closely related to variations in North Atlantic Deep Water formation.

\section{Introduction}

A more sluggish deep-ocean ventilation combined with a more efficient biological pump is widely thought to facilitate enhanced carbon sequestration in the ocean interior, leading to atmospheric $\mathrm{CO}_{2}$ drawdown during glacial cold periods (Sigman and Boyle, 2000). These changes are tightly coupled to bottom water oxygenation and sedimentary redox changes 
on both millennial and orbital timescales (Hoogakker et al., 2015; Jaccard and Galbraith, 2012; Sigman and Boyle, 2000). Reconstruction of past sedimentary oxygenation is therefore crucial for understanding changes in export productivity and renewal of deep-ocean circulation (Nameroff et al., 2004). Previous studies from the North Pacific margins as well as the open subarctic Pacific have identified drastic variations in export productivity and ocean oxygen levels at millennial and orbital timescales using diverse proxies such as trace elements (Cartapanis et al., 2011; Chang et al., 2014; Jaccard et al., 2009; Zou et al., 2012), benthic foraminiferal assemblages (Ohkushi et al., 2016, 2013; Shibahara et al., 2007) and nitrogen isotopic composition $\left(\delta^{15} \mathrm{~N}\right)$ of organic matter (Addison et al., 2012; Chang et al., 2014; Galbraith et al., 2004; Riethdorf et al., 2016) in marine sediment cores. These studies suggested that both the North Pacific Intermediate Water (NPIW) and export of organic matter regulate the sedimentary oxygenation variation during the last glaciation and Holocene in the subarctic Pacific. By contrast, little information exists on millennial-scale oxygenation changes to date in the western subtropical North Pacific (WSTNP).

The modern NPIW precursor waters are mainly sourced from the NW Pacific marginal seas (Shcherbina et al., 2003; Talley, 1993; You et al., 2000), spreading into the subtropical North Pacific at intermediate depths of 300 to $800 \mathrm{~m}$ (Talley, 1993). The pathway and circulation of the NPIW have been identified by You (2003), which suggested that cabbeling, a mixing process to form a new water mass with increased density than that of the parent water masses, is the principle mechanism responsible for transforming subpolar source waters into the subtropical NPIW along the subarctic-tropical frontal zone. More specifically, a small subpolar input of about $2 \mathrm{~Sv}\left(1 \mathrm{~Sv}=10^{6} \mathrm{~m}^{3} \mathrm{~s}^{-1}\right)$ is sufficient for subtropical ventilation (You et al., 2003). Benthic foraminiferal $\delta^{13} \mathrm{C}$, a quasi-conservative tracer for water mass, from the North Pacific indicates an enhanced ventilation (higher $\delta^{13} \mathrm{C}$ ) at water depths of $<2000 \mathrm{~m}$ during the last glacial period (Keigwin, 1998; Matsumoto et al., 2002). Furthermore, on the basis of both radiocarbon data and modeling results, Okazaki et al. (2010) suggested the formation of deep water in the North Pacific during the early deglaciation in Heinrich Stadial 1 (HS1). Enhanced NPIW penetration was further explored using numerical model simulations (Chikamoto et al., 2012; Gong et al., 2019; Okazaki et al., 2010). In contrast, substantial effects of an intensified NPIW formation during Marine Isotope Stage (MIS) 2 and 6 on the ventilation and nutrient characteristics of the lower-latitude mid-depth eastern equatorial Pacific have been suggested by recent studies (Max et al., 2017; Rippert et al., 2017). The downstream effects of an intensified NPIW are also reflected in the record of $\delta^{13} \mathrm{C}$ of Cibicides wuellerstorfi in core PN-3 from the middle Okinawa Trough (OT), where lower deglacial $\delta^{13} \mathrm{C}$ values were attributed to enhanced $\mathrm{OC}$ accumulation rates due to higher surface productivity by Wahyudi and Minagawa (1997).
The Okinawa Trough is separated from the Philippine Sea by the Ryukyu Islands and is an important channel of the northern extension of the Kuroshio in the WSTNP (Fig. 1). Initially the OT opened at the Middle Miocene (Sibuet et al., 1987) and since then, it has been a depositional center in the East China Sea (ECS), receiving large sediment supplies from nearby rivers (Chang et al., 2009). Surface oceanographic characteristics of the OT over glacial-interglacial cycles are largely influenced by the Kuroshio and ECS Coastal Water (Shi et al., 2014); the latter is related to the strength of the summer East Asian monsoon (EAM) whose source is the western tropical Pacific. Modern physical oceanographic investigations showed that intermediate waters in the OT are mainly derived from horizontal advection and mixing of the NPIW and South China Sea Intermediate Water (Nakamura et al., 2013). These waters intrude into the OT in two ways: (i) the deeper part of the Kuroshio enters the OT through the channel east of Taiwan (sill depth $775 \mathrm{~m}$ ) and (ii) they enter through the Kerama Gap (sill depth $1100 \mathrm{~m}$ ). In the northern OT, the subsurface water mainly flows through horizontal advection through the Kerama Gap from the Philippine Sea (Nakamura et al., 2013). Recently, Nishina et al. (2016) found that an overflow through the Kerama Gap controls the modern deepwater ventilation in the southern OT.

Both surface characteristics and deep ventilation in the OT varied significantly since the last glaciation. During the last glacial period, the mainstream of the Kuroshio likely migrated to the east side of the Ryukyu Islands or also became weaker due to lower sea levels (Shi et al., 2014; Ujiié and Ujiié, 1999; Ujiié et al., 2003) and the hypothetical emergence of a Ryukyu-Taiwan land bridge (Ujiié and Ujiié, 1999). In a recent study, based on the $\mathrm{Mg} / \mathrm{Ca}$-derived temperatures in surface and thermocline waters and planktic foraminiferal indicators of water masses from two sediment cores located in the northern and southern OT, Ujiié et al. (2016) argued that the hydrological conditions of the North Pacific Subtropical Gyre since MIS 7 are modulated by the interaction between the Kuroshio and the NPIW. Besides the Kuroshio, the flux of East Asian rivers to the ECS, which is related to the summer EAM and the sea level oscillations coupled with topography have also been regulating the surface hydrography in the OT (Chang et al., 2009; Kubota et al., 2010; Sun et al., 2005; Yu et al., 2009).

Based on benthic foraminiferal assemblages, previous studies have implied a reduced oxygenation in deep waters of the middle and southern OT during the last deglacial period (Jian et al., 1996; Li et al., 2005) but a strong ventilation during the Last Glacial Maximum (LGM) and the Holocene (Jian et al., 1996; Kao et al., 2005). High sedimentary $\delta^{15} \mathrm{~N}$ values, an indicator of increased denitrification in the subsurface water column, also occurred during the late deglaciation in the middle OT (Kao et al., 2008). Inconsistent with these results, Dou et al. (2015) suggested an oxic depositional environment during the last deglaciation in the southern OT, based on weak positive cerium anomalies. Furthermore, Kao 

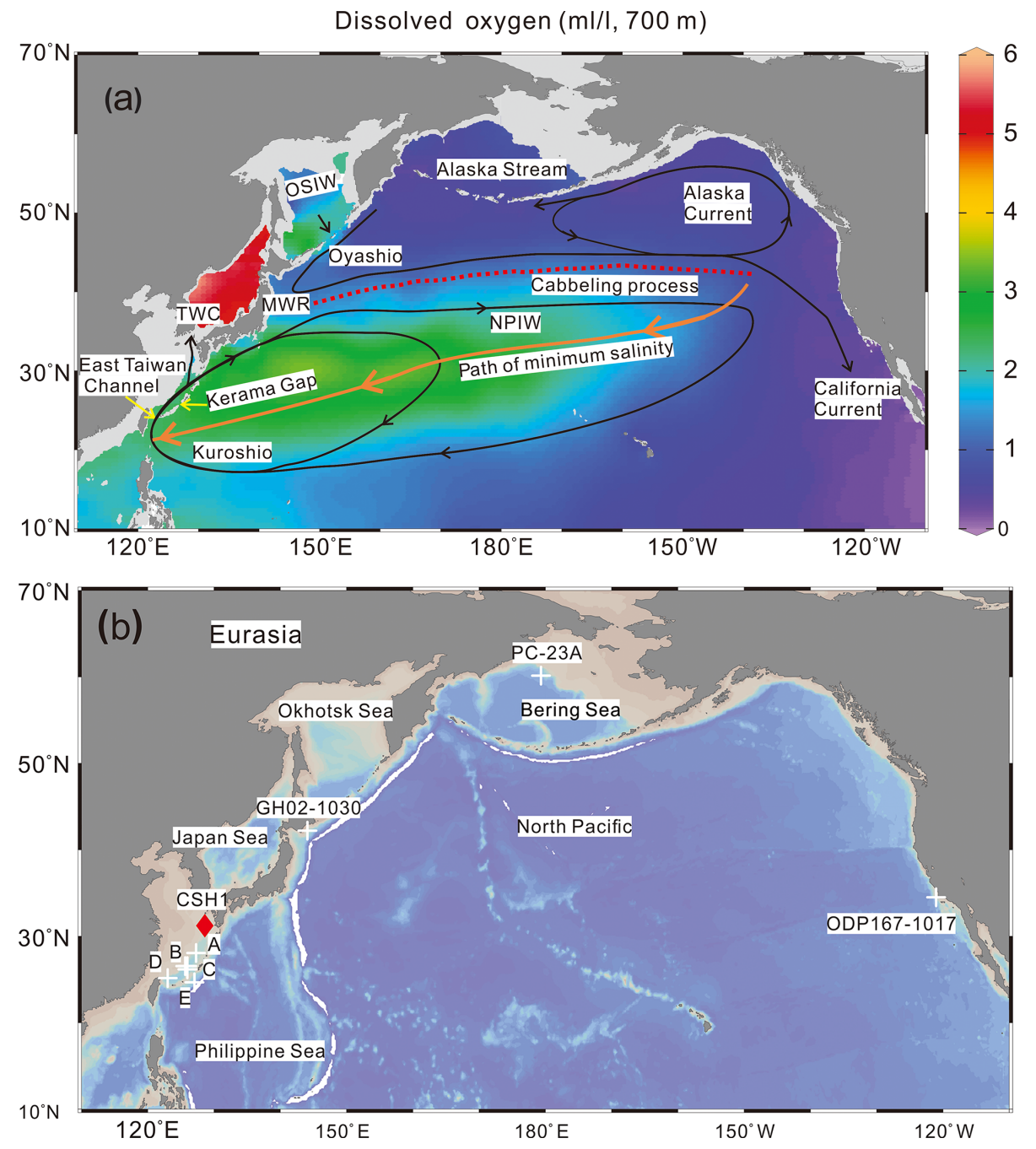

Figure 1. (a) Spatial distribution of dissolved oxygen content at $700 \mathrm{~m}$ water depth in the North Pacific. Black arrows denote simplified Kuroshio and Oyashio circulations and the North Pacific Intermediate Water (NPIW) in the North Pacific. The dashed thick red line indicates a transformation of Okhotsk Sea Intermediate Water (OSIW) by cabbeling of the subtropical NPIW along the subarctic-tropical frontal zone (You, 2003). The solid light brown line with arrows indicates the spreading path of the subtropical NPIW from the northeast North Pacific southward toward the low-latitude northwest North Pacific (You, 2003). Solid yellow lines with arrows represent the two passages through which the NPIW enters into the Okinawa Trough. (b) Location of sediment core CSH1 investigated in this study (red diamond). Also shown are locations of sediment cores PN-3, E017, 255 and MD01-2404 investigated previously from the Okinawa Trough, GH08-2004 from the east of Ryukyu Island, GH02-1030 off the east of Japan, PC-23A from the Bering Sea and ODP Site 1017 from the northeastern Pacific. Letters A to E represent the sediment cores from and near the OT. The detailed information for these cores is shown in Table 1. Panels (a, b) are plotted with Ocean Data View (Schlitzer, 2016) using all available data from 1955 to 2012 from World Ocean Circulation Experiment database.

et al. (2006) hypothesized a reduced ventilation of deepwater in the OT during the LGM due to the reduction of $\mathrm{KC}$ inflow using a 3-D ocean model. Thus, the patterns and reasons that caused sedimentary oxygenation in the OT remain controversial.

\section{Paleo-redox proxies}

The sedimentary redox conditions are governed by the rate of oxygen supply from the overlying bottom water and the rate of oxygen removal from pore water (Jaccard et al., 2016), processes that are related to the supply of oxygen by ocean circulation and organic matter respiration, respectively. Contrasting geochemical behaviors of redox-sensitive trace metals (Mn, Mo, U, etc.) have been used to reconstruct bottom water and sedimentary oxygen changes (Algeo, 2004; Algeo 
Table 1. Locations of different sediment core records and their source references discussed in the text.

\begin{tabular}{llccrll}
\hline $\begin{array}{l}\text { Label in } \\
\text { Fig. 1b }\end{array}$ & Station & $\begin{array}{r}\text { Latitude } \\
\left({ }^{\circ} \mathrm{N}\right)\end{array}$ & $\begin{array}{c}\text { Longitude } \\
\left({ }^{\circ} \mathrm{E}\right)\end{array}$ & $\begin{array}{r}\text { Water depth } \\
(\mathrm{m})\end{array}$ & Area & Reference \\
\hline & CSH1 & 31.23 & 128.72 & 703 & Okinawa Trough & this study \\
A & PN-3 & 28.10 & 127.34 & 1058 & Okinawa Trough & Wahyudi and Minagawa (1997) \\
B & MD01-2404 & 26.65 & 125.81 & 1397 & Okinawa Trough & Kao et al. (2008) \\
C & E017 & 26.57 & 126.02 & 1826 & Okinawa Trough & Li et al. (2005) \\
D & 255 & 25.20 & 123.12 & 1575 & Okinawa Trough & Jian et al. (1996) \\
E & GH08-2004 & 26.21 & 127.09 & 1166 & East of Ryukyu Island & Kubota et al. (2015) \\
& GH02-1030 & 42.23 & 144.21 & 1212 & Off Japan & Sagawa and Ikehara (2008) \\
& PC-23A & 60.16 & 179.46 & 1002 & Bering Sea & Rella et al. (2012) \\
& ODP Site1017 & 34.54 & 239.11 & 955 & NE Pacific & Cannariato and Kennett (1999) \\
\hline
\end{tabular}

and Lyons, 2006; Crusius et al., 1996; Dean et al., 1997; Tribovillard et al., 2006; Zou et al., 2012), as their concentrations readily respond to redox conditions of the depositional environment (Morford and Emerson, 1999).

In general, enrichment of Mn with higher speciation states - Mn(III) and Mn(IV) - in the form of manganese oxide coatings is observed in marine sediments, when oxic conditions spread into greater sediment depths as a result of low organic matter degradation rates and well-ventilated bottom water (Burdige, 1993). Under reducing conditions, the authigenic fraction of $\mathrm{Mn}$ (as opposed to its detrital background) is released as dissolved $\mathrm{Mn}$ (II) species into the pore water and thus its concentration is usually low in suboxic $\left(\mathrm{O}_{2}\right.$ and $\mathrm{HS}^{-}$absent) and anoxic (HS ${ }^{-}$present) sediments. In addition, when Mn enrichment occurs in oxic sediments as solidphase Mn oxyhydroxides, it may lead to co-precipitation of other elements, such as Mo (Nameroff et al., 2002).

The elements Mo and $U$ behave conservatively in oxygenated seawater but are preferentially enriched in oxygendepleted water (Morford and Emerson, 1999). However, these two trace metals behave differently in several ways. Molybdenum can be enriched in both oxic sediments, such as the near surface manganese-rich horizons in continental margin environments (Shimmield and Price, 1986) and in anoxic sediments (Nameroff et al., 2002). Under anoxic conditions, Mo can be reduced either from the +6 oxidation state to insoluble $\mathrm{MoS}_{2}$ - this process is known to occur only under extremely reducing conditions such as hydrothermal and/or diagenesis (Dahl et al., 2010; Helz et al., 1996) - or be converted to particle-reactive thiomolybdates (Vorlicek and Helz, 2002). Zheng et al. (2000) suggested two critical thresholds for Mo scavenging from seawater: $0.1 \mu \mathrm{M}$ hydrogen sulfide $\left(\mathrm{H}_{2} \mathrm{~S}\right)$ for $\mathrm{Fe}-\mathrm{S}-\mathrm{Mo}$ co-precipitation and $100 \mu \mathrm{M} \mathrm{H}_{2} \mathrm{~S}$ for Mo scavenging as Mo-S or as particlebound Mo without Fe. Although Crusius et al. (1996) noted insignificant enrichment of sedimentary Mo under suboxic conditions, Scott et al. (2008) argued that burial flux of Mo is not so low in suboxic environments. An excess concentration of Mo (Moexcess) in sediments thus suggests the accumulation of sediments either in anoxic $\left(\mathrm{H}_{2} \mathrm{~S}\right.$ occurrence $)$ or well-oxygenated conditions (if $\mathrm{Mo}_{\text {excess }}$ is in association with manganese oxides).

In general, $\mathrm{U}$ is enriched in anoxic sediments $(>1 \mu \mathrm{M}$ $\mathrm{H}_{2} \mathrm{~S}$ ) but not in oxic sediments $\left(>10 \mu \mathrm{M} \mathrm{O}_{2}\right)$ (Nameroff et al., 2002). Accumulation of $U$ depends on the content of reactive organic matter (Sundby et al., 2004) and U precipitates as uraninite $\left(\mathrm{UO}_{2}\right)$ during the conversion of $\mathrm{Fe}$ (III) to $\mathrm{Fe}$ (II) in suboxic conditions (Morford and Emerson, 1999; Zheng et al., 2002). One of the primary removal mechanisms for $\mathrm{U}$ from the ocean is via diffusion across the sediment-water interface of reducing sediments (Klinkhammer and Palmer, 1991). Under suboxic conditions, soluble U (VI) is reduced to insoluble $\mathrm{U}(\mathrm{IV})$, but free sulfide is not required for $\mathrm{U}$ precipitation (McManus et al., 2005). Jaccard et al. (2009) suggested that the presence of an excess concentration of $U$ $\left(\mathrm{U}_{\text {excess }}\right)$ in the absence of Mo enrichment is indicative of a suboxic (but not a sulfidic) condition within the diffusional range of the sediment-water interface. Felsic volcanism is also a primary source of uranium (Maithani and Srinivasan, 2011). Therefore, the potential input of uranium from active volcanic sources around the northwestern Pacific to the adjacent sediments should not be neglected.

In this study, we investigate a suite of redox-sensitive elements and the ratio of $\mathrm{Mo} / \mathrm{Mn}$ along with productivity proxies from a sediment core retrieved from the northern OT in order to reconstruct the sedimentary oxygenation in the WSTNP over the last $50 \mathrm{ka}$. Based on that, we propose that multiple factors, such as NPIW ventilation, the strength of the Kuroshio Current and export productivity, control the bottom sedimentary oxygenation in the OT on millennial timescales since the last glacial period.

\section{Oceanographic setting}

Surface hydrographic characteristics of the OT are mainly controlled by the warmer, more saline, oligotrophic Kuroshio water and cooler, less saline, nutrient-rich Changjiang Diluted Water, and the modern flow path of the former is influenced by the bathymetry of the OT (Fig. 1a). The Kuroshio Current originates from the North Equatorial Current and 
flows into the ECS from the Philippine Sea through the Suao-Yonaguni Depression. In the northern OT, Tsushima Warm Current (TWC), a branch of the Kuroshio, flows into the Sea of Japan through the shallow Tsushima Strait. The volume transport of the Kuroshio varies seasonally due to the influence of the EAM with a maximum of $24 \mathrm{~Sv}$ in summer and a minimum of $20 \mathrm{~Sv}$ in autumn across the east of Taiwan (Qu and Lukas, 2003).

A lower sea surface salinity (SSS) zone in summer relative to the one in winter in the ECS migrates toward the east of OT, indicating an enhanced impact of the Changjiang discharge associated with summer EAM (Fig. 2a and b). An estimated $\sim 80 \%$ of the mean annual discharge of the river Changjiang is supplied to the ECS (Ichikawa and Beardsley, 2002) and in situ observational data show a pronounced negative correlation between the Changjiang discharge and SSS in July (Delcroix and Murtugudde, 2002). Consistently, previous studies from the OT reported such a close relationship between summer EAM and SSS back to the late Pleistocene (Chang et al., 2009; Clemens et al., 2018; Kubota et al., 2010; Sun et al., 2005).

Despite the effects of EAM and the Kuroshio, evidence of geochemical tracers (temperature, salinity, oxygen, nutrients and radiocarbon) collected during the World Ocean Circulation Experiment (WOCE) in the Pacific (transects P24 and P03) favors the presence of low-salinity, nutrient-enriched intermediate and deep waters (Talley, 2007). Dissolved oxygen content is $<100 \mu \mathrm{mol} \mathrm{kg}^{-1}$ at water depths below $600 \mathrm{~m}$ in the OT, along WOCE transects PC03 and PC24 (Talley, 2007). Modern oceanographic observations at the Kerama Gap reveal that upwelling in the OT is associated with the inflow of the NPIW and studies using a box model predicted that overflow through the Kerama Gap is responsible for upwelling (3.8-7.6 $\times 10^{-6} \mathrm{~m} \mathrm{~s}^{-1}$ ) (Nakamura et al., 2013; Nishina et al., 2016).

\section{Materials and methods}

\subsection{Chronostratigraphy of core $\mathrm{CSH} 1$}

A $17.3 \mathrm{~m}$ long sediment core CSH $1 \quad\left(31^{\circ} 13.7^{\prime} \mathrm{N}\right.$, $128^{\circ} 43.4^{\prime} \mathrm{E}$; water depth: $703 \mathrm{~m}$ ) was collected from the northern OT, close to the main stream of Tsushima Warm Current (TWC) (Fig. 1b) and within the depth of the NPIW (Fig. 1c) using a piston corer during Xiangyanghong09 Cruise in 1998, carried out by the First Institute of Oceanography, Ministry of Natural Resources of China. This location is enabling us to reconstruct millennial-scale changes in the properties of the TWC and NPIW. Core CSH1 mainly consists of clayey silt and silt with occurrence of plant debris at some depth intervals (Ge et al., 2007) (Fig. 3a). In addition, three layers of volcanic ash were observed at depths of 74-106, 782-794 and 1570-1602 cm. These three intervals can be correlated with well-known ash layers, Kikai-Akahoya (K-Ah; 7.3 ka), Aira-Tanzawa (AT;
$29.24 \mathrm{ka}$ ) and Aso-4 (roughly around MIS 5a) (Machida, 1999), respectively. The core was split and subsampled at $4 \mathrm{~cm}$ interval and then stored in the China Ocean Sample Repository at $4{ }^{\circ} \mathrm{C}$ until analysis.

Previously, paleoceanographic studies have been conducted and a set of data has been investigated for core CSH1, including the contents of planktic foraminifers as well as their carbon $\left(\delta^{13} \mathrm{C}\right)$ and oxygen isotope $\left(\delta^{18} \mathrm{O}\right)$ compositions (Shi et al., 2014), pollen (Chen et al., 2006), paleomagnetism (Ge et al., 2007) and $\mathrm{CaCO}_{3}$ (Wu et al., 2004). An age model for this core has been constructed by using 10 Accelerator Mass Spectrometry (AMS) ${ }^{14} \mathrm{C}$ dates and six oxygen isotope $\left(\delta^{18} \mathrm{O}\right)$ age control points. The whole $17.3 \mathrm{~m}$ core contains ca. $88 \mathrm{ka}$ long record of continuous sedimentation (Shi et al., 2014).

Notably, the original age model, which used constant radiocarbon reservoir ages throughout core CSH1 are suitable to reveal orbital-scale Kuroshio variations (Shi et al., 2014) but insufficient to investigate millennial-scale climatic events. The occurrence of a higher abundance of Neogloboquadrina pachyderma (dextral), e.g., during warmer intervals, such as the Bölling-Alleröd (B/A), has been challenging to explain. On the other hand, paired measurements of ${ }^{14} \mathrm{C} /{ }^{12} \mathrm{C}$ and ${ }^{230} \mathrm{Th}$ ages from Hulu Cave stalagmites suggest magnetic field changes have greatly contributed to high atmospheric ${ }^{14} \mathrm{C} /{ }^{12} \mathrm{C}$ values at $\mathrm{HS} 4$ and the Younger Dryas (YD) (Cheng et al., 2018). Thus a constant reservoir age $(\Delta R=0)$ assumed when calibrating foraminiferal radiocarbon dates using CALIB 6 software and the Marine 13 calibration dataset (Reimer et al., 2013) for core CSH1 may cause large chronological uncertainties.

Here, we recalibrated the radiocarbon dates using updated CALIB 7.04 software with Marine 13 calibration dataset (Reimer et al., 2013). Moreover, on the basis of significant correlation between planktic foraminifera species Globigerinoides ruber $\delta^{18} \mathrm{O}$ and Chinese stalagmite $\delta^{18} \mathrm{O}$ (Cheng et al., 2016), a proxy of summer EAM related to SSS of the ECS, we improve the age model for core CSH1 (Fig. 3b-d). Overall, the new chronological framework is similar to the one previously reported by Shi et al. (2014) but with more dates. In order to compare with published results associated with ventilation changes in the North Pacific, here we mainly report the history of sedimentary oxygenation in the northern OT since the last glacial period. Linear sedimentation rate varied between $\sim 10$ and $40 \mathrm{~cm} \mathrm{ka}^{-1}$ with higher sedimentation rates (around $30-40 \mathrm{~cm} \mathrm{ka}^{-1}$ ) between $\sim 24$ and $32.5 \mathrm{ka}$. Variation in sedimentation rate has been attributed to changes in eustatic sea level, summer EAM intensity, path and/or intensity of Kuroshio Current. Generally, sea level is thought to be the first-order factor for controlling linear sedimentation rate changes (Beny et al., 2018; Li et al., 2015; Zhao et al., 2017). The new age control points are shown in Table 2 . 

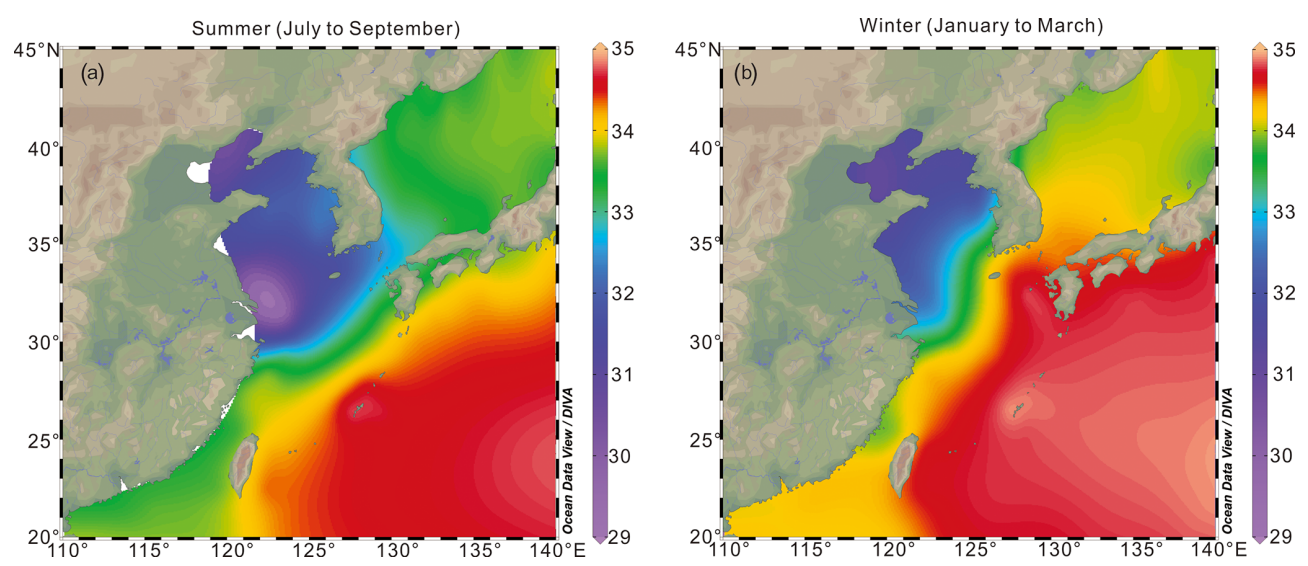

Figure 2. Spatial distribution of sea surface salinity in the East China Sea. (a) Summer (July to September); (b) winter (January to March). Lower sea surface salinity in summer relative to that of winter indicates strong effects of summer East Asian monsoon. Panels (a, b) are plotted with Ocean Data View (Schlitzer, 2016) using all available data from 1955 to 2012 from World Ocean Circulation Experiment database.
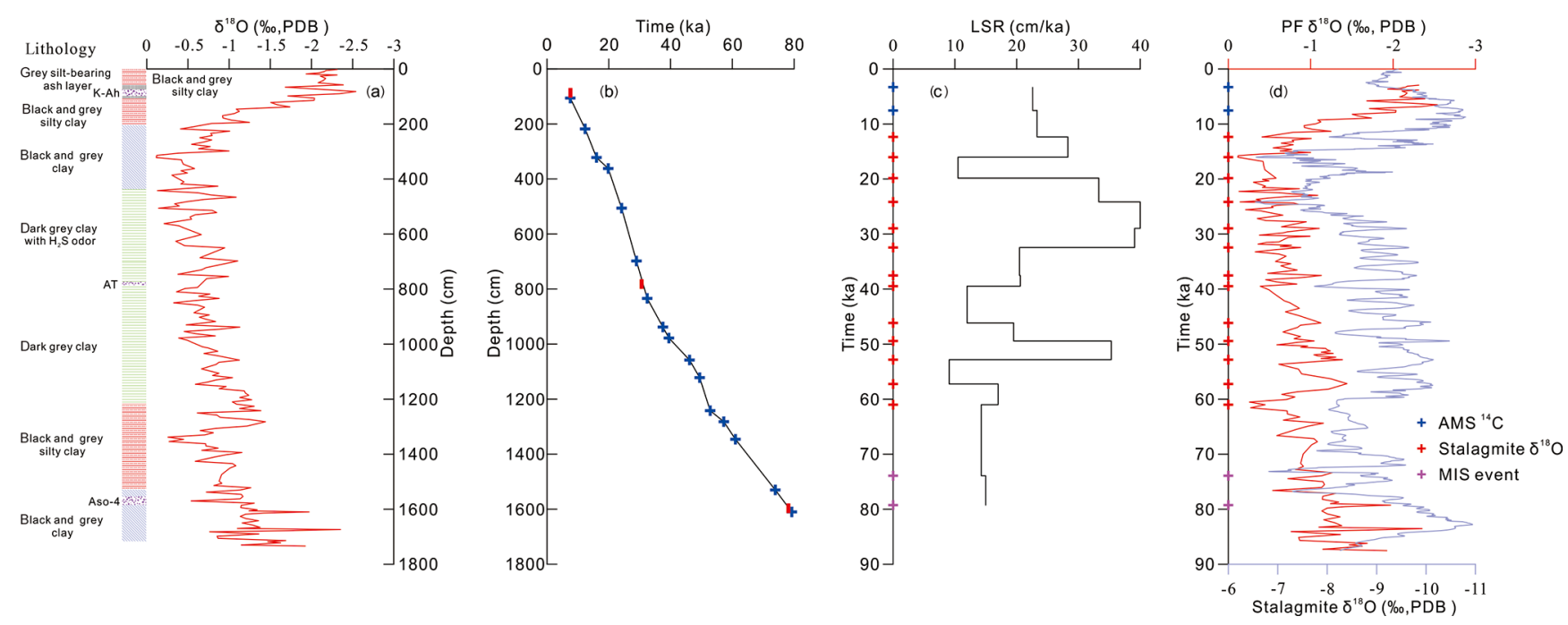

Figure 3. (a) Lithology and oxygen isotope $\left(\delta^{18} \mathrm{O}\right)$ profile of planktic foraminifera species Globigerinoides ruber (G. ruber) in core CSH1. (b) Plot of ages vs. depth for core CSH1. Three known ash layers are indicated by solid red rectangles. (c) Time series of linear sedimentation rate (LSR) from core CSH1. (d) On the basis of reference by Cheng et al. (2016), the composite record of Asian Monsoon is constructed from speleothem $\delta^{18} \mathrm{O}$ records from these three Sanbao, Hulu and Dongge caves. Tie points for CSH1 core chronology (Table 2) in (c, d) are designated by colored crosses.

\subsection{Chemical analyses}

Sediment subsamples for geochemical analyses were freezedried and ground to a fine powder with an agate mortar and pestle. Based on the age model, 85 subsamples from core CSH1, representing a temporal resolution of about 600 years (every $4 \mathrm{~cm}$ interval) were selected for detailed geochemical analyses of major and minor elements, and total carbon (TC), organic carbon (TOC) and nitrogen (TN) contents. The pretreatment of sediment and other analytical methods have been reported elsewhere (Zou et al., 2012).

$\mathrm{TC}$ and TN were determined with an elemental analyzer (EA; Vario EL III, Elementar Analysensysteme GmbH) in the Key Laboratory of Marine Sediment and Environment Geology, First Institute of Oceanography, Ministry of Natural Resources of China, Qingdao. Carbonate was removed from sediments by adding $1 \mathrm{M} \mathrm{HCl}$ to the homogenized sediments for a total organic carbon (TOC) analysis using the same equipment. The content of calcium carbonate $\left(\mathrm{CaCO}_{3}\right)$ was calculated using the equation:

$\mathrm{CaCO}_{3}=(\mathrm{TC}-\mathrm{TOC}) \times 8.33$,

where 8.33 is the ratio between the molecular weight of carbonate and the atomic weight of carbon. A national reference material (GSD-9), a blank sample and replicated sam- 
Table 2. Age control points adopted between planktic foraminifera species Globigerinoides ruber $\delta^{18} \mathrm{O}$ of core CSH1 and Chinese stalagmite $\delta^{18} \mathrm{O}$ (Cheng et al., 2016) for tuning the age model between 10 and $60 \mathrm{ka}$ in this study. A linear interpolation was assumed between age control points.

\begin{tabular}{lcrrlrl}
\hline $\begin{array}{l}\text { Depth } \\
(\mathrm{cm})\end{array}$ & $\begin{array}{c}\text { AMS }{ }^{14} \mathrm{C} \\
\text { (year) }\end{array}$ & $\begin{array}{r}\text { Error } \\
(\text { year })\end{array}$ & $\begin{array}{r}\text { Calibrated } \\
\text { Age(year) }\end{array}$ & Tie point type & $\begin{array}{r}\text { LSR } \\
\left(\mathrm{cm} \mathrm{ka}^{-1}\right)\end{array}$ & Source \\
\hline 10 & 3420 & \pm 35 & 3296 & ${ }^{14} \mathrm{C}$ & & Shi et al. (2014) \\
106 & 7060 & \pm 40 & 7545 & ${ }^{14} \mathrm{C}$ & 22.59 & Shi et al. (2014) \\
218 & & 12352 & Stalagmite, YD & 23.30 & This study \\
322 & & 16029 & Stalagmite, H1 & 28.28 & This study \\
362 & & 19838 & Stalagmite & 10.50 & This study \\
506 & & 24163 & Stalagmite, H2 & 33.29 & This study \\
698 & & 28963 & Stalagmite, DO4 & 40.00 & This study \\
834 & & 32442 & Stalagmite, DO5 & 39.09 & This study \\
938 & & 37526 & Stalagmite, DO8 & 20.46 & This study \\
978 & & 39468 & Stalagmite, H4 & 20.60 & This study \\
1058 & & 46151 & Stalagmite, DO12 & 11.97 & This study \\
1122 & & & 49432 & Stalagmite, DO13 & 19.51 & This study \\
1242 & & & 52831 & Stalagmite, DO14 & 35.30 & This study \\
1282 & & & 57241 & Stalagmite, DO16 & 9.07 & This study \\
1346 & & & 73907 & Stalagmite, H6 & 16.99 & This study \\
1530 & & & MIS4/5 & 14.26 & Shi et al. (2014) \\
1610 & & & & & 14.98 & Shi et al. (2014) \\
\hline
\end{tabular}

ples were used to control the analytical process. The relative standard deviation of the GSD-9 for TC, TN and TOC is $\leq 3.4 \%$.

About $0.5 \mathrm{~g}$ of sediment powder was digested in double-distilled $\mathrm{HF}: \mathrm{HNO}_{3}(3: 1)$, followed by concentrated $\mathrm{HClO}_{4}$, and then redissolved in $5 \% \mathrm{HNO}_{3}$. Selected major and minor elements such as aluminum ( $\mathrm{Al}$ ) and manganese $(\mathrm{Mn})$ were determined by inductively coupled plasma optical emission spectroscopy (ICP-OES; Thermo Scientific iCAP 6000, Thermo Fisher Scientific), as detailed elsewhere (Zou et al., 2012). In addition, Mo and U were analyzed with inductively coupled plasma mass spectrometry (ICPMS; Thermo Scientific XSERIES 2, Thermo Fisher Scientific), as described in Zou et al. (2012). Precision for most elements in the reference material GSD- 9 is $\leq 5 \%$ relative standard deviation. The excess fractions of $U$ and Mo were estimated by normalization to $\mathrm{Al}$ as follows:

Excess fraction $=$ total ${ }_{\text {element }}-\left(\right.$ element $/ \mathrm{Al}_{\text {average shale }} \times$ $\mathrm{Al}$ ), with $\mathrm{U} / \mathrm{Al}_{\text {average shale }}=0.307 \times 10^{-6}$ and $\mathrm{Mo} / \mathrm{Al}_{\text {average shale }}=0.295 \times 10^{-6}(\mathrm{Li}$ and Schoonmaker, 2014).

In addition, given the different geochemical behaviors of $\mathrm{Mn}$ and Mo and co-precipitation and adsorption processes associated with the redox cycling of $\mathrm{Mn}$, we calculated the ratio of Mo to Mn, assuming that a higher Mo/Mn ratio indicates a lower oxygen content in the depositional environment and vice versa. In combination with the concentration of excess uranium, we infer the history of sedimentary oxygenation in the subtropical North Pacific since the last glaciation.

\section{Results}

\subsection{TOC, $\mathrm{TN}$ and $\mathrm{CaCO}_{3}$}

The content of $\mathrm{CaCO}_{3}$ varies from $8.8 \%$ to $35 \%$ (Fig. 4a), and it mostly shows higher values with increasing trends during the last deglaciation. In contrast, the content of $\mathrm{CaCO}_{3}$ is low and exhibits decreasing trends during the late MIS 3 and the LGM (Fig. 4a). TN content shows a larger variation compared to TOC (Fig. 4b), but it still strongly correlates with TOC $(r=0.74, p<0.01)$ throughout the entire core. Concentration of TOC ranges from $0.5 \%$ to $2.1 \%$, and it shows higher values with stable trends during the last glacial phase (MIS 3) (Fig. 4c). Molar ratios of TOC/TN vary around 10, with higher ratios at the transition into the LGM (Fig. 4d), corresponding to a higher linear sedimentation rate (Fig. 4e).

Both TOC and $\mathrm{CaCO}_{3}$ have been used as proxies for the reconstruction of past export productivity (Cartapanis et al., 2011; Lembke-Jene et al., 2017; Rühlemann et al., 1999). Molar $\mathrm{C} / \mathrm{N}$ ratios of $>10$ (Fig. $4 \mathrm{c}$ ) suggest that terrigenous organic sources significantly contribute to the TOC concentration in core CSH1. The TOC content therefore may not be a reliable proxy for the reconstruction of surface water export productivity during times of the LGM and late deglaciation, when maxima in $\mathrm{C} / \mathrm{N}$ ratios co-occur with decoupled trends between $\mathrm{CaCO}_{3}$ and TOC concentrations.

Several lines of evidence support $\mathrm{CaCO}_{3}$ as a reliable productivity proxy, particularly during the last deglaciation. The strong negative correlation coefficient $(r=-0.85 ; p<0.01)$ between $\mathrm{Al}$ and $\mathrm{CaCO}_{3}$ in sediments throughout core $\mathrm{CSH} 1$ confirms the biogenic origin of $\mathrm{CaCO}_{3}$ against terrigenous 


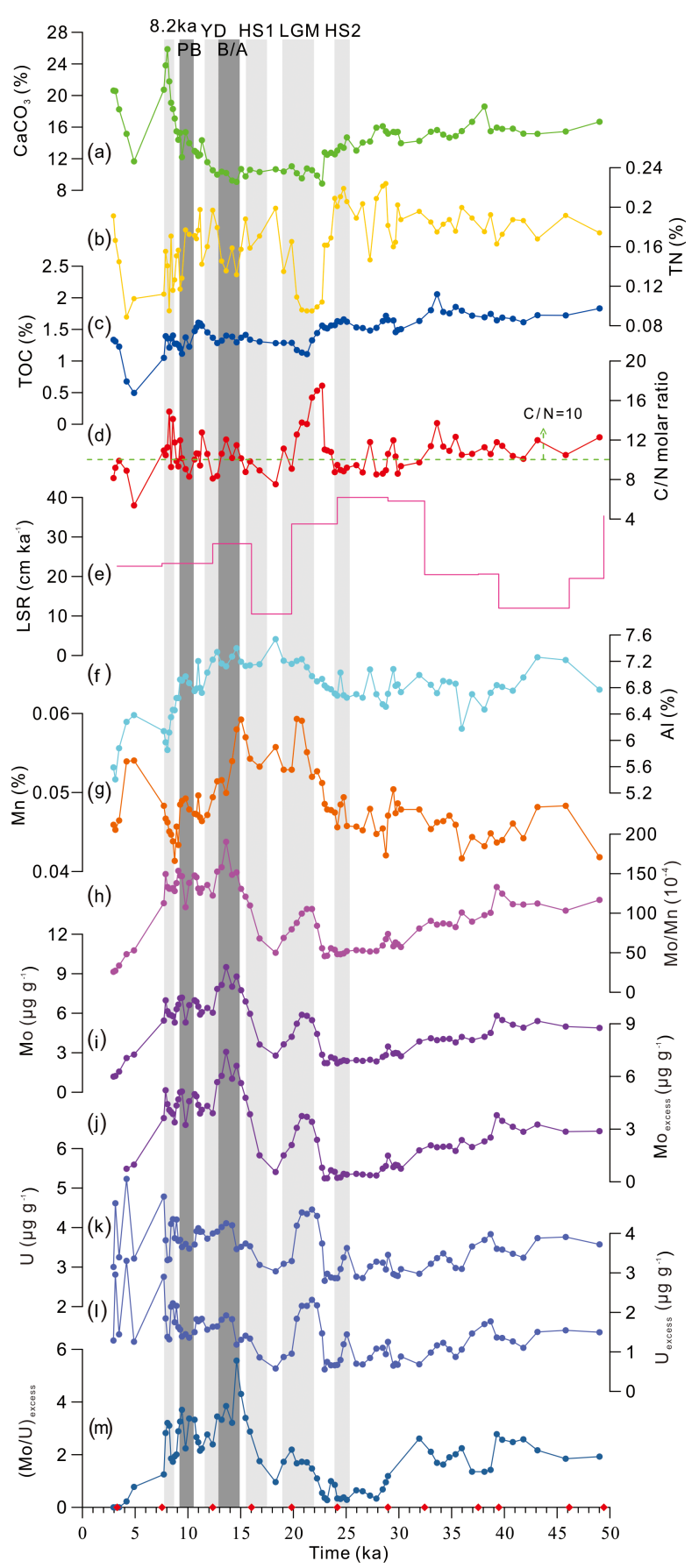

Figure 4. Age vs. (a) $\mathrm{CaCO}_{3}$ concentration, (b) total nitrogen (TN) concentration, (c) total organic carbon (TOC) concentration, (d) $\mathrm{C} / \mathrm{N}$ molar ratio, (e) linear sedimentation rate (LSR), (f) Al concentration, (g) Mn concentration, (h) Mo/Mn ratio, (i) Mo concentration, (j) excess Mo concentration, (k) U concentration, (l) excess $\mathrm{U}$ concentration and $(\mathbf{m})(\mathrm{Mo} / \mathrm{U})_{\text {excess }}$ ratio in core CSH1. Light gray and dark gray vertical bars indicate different sediment intervals in core CSH1. The labels $8.2 \mathrm{ka}, \mathrm{PB}, \mathrm{YD}, \mathrm{B} / \mathrm{A}, \mathrm{HS} 1$, LGM and HS2 refer to the 8200-year cold event, Preboreal, Younger Dryas, Bölling-Alleröd, Heinrich Stadial 1, Last Glacial Maximum and Heinrich Stadial 2, respectively, which were identified in core CSH1. Red solid diamonds in (m) indicate the age control points.
Al (Fig. 4f). Generally, terrigenous dilution decreases concentrations of $\mathrm{CaCO}_{3}$. An inconsistent relationship between $\mathrm{CaCO}_{3}$ contents and sedimentation rates indicates a minor effect of dilution on $\mathrm{CaCO}_{3}$. Furthermore, the increasing trend in $\mathrm{CaCO}_{3}$ associated with a high sedimentation rate during the last deglacial interval indicates a substantial increase in export productivity (Fig. $4 \mathrm{a}$ and d). The high coherence between the $\mathrm{CaCO}_{3}$ content and alkenone-derived sea surface water (SST) (Shi et al., 2014) indicates a direct control on $\mathrm{CaCO}_{3}$ by SST. Moreover, a detailed comparison between $\mathrm{CaCO}_{3}$ concentrations and the previously published foraminiferal fragmentation ratio (Wu et al., 2004) shows, apart from a small portion within the LGM, no clear covariation between them. These pieces of evidence suggest that $\mathrm{CaCO}_{3}$ changes are driven primarily by variations in carbonate primary production and are not overprinted by secondary processes, such as carbonate dissolution through changes in the lysocline depth and dilution by terrigenous materials. Likewise, a similar deglacial trend in $\mathrm{CaCO}_{3}$ is also observed in core MD01-2404 (Chang et al., 2009), indicating a ubiquitous, not local picture in the OT. All these lines of evidence thus support $\mathrm{CaCO}_{3}$ of core $\mathrm{CSH} 1$ as a reliable productivity proxy to a first-order approximation.

\subsection{Redox-sensitive elements}

Figure 4 shows time series of selected redox-sensitive elements (RSEs) and proxies derived from them. Mn shows higher concentrations during the LGM and HS1 (16-22 ka) and middle-late Holocene but lower concentrations during the last deglacial and Preboreal periods (15.8-9.5 ka, Fig. 4g). Generally, concentrations of excess Mo and excess $\mathrm{U}$ (Fig. $4 \mathrm{j}$ and 1 ) show coherent patterns with those of Mo and $U$ (Fig. $4 i$ and k), but both are out of phase with Mn over the last glacial period (Fig. 4h). Pronounced variations in $\mathrm{U}$ concentration after $8.5 \mathrm{ka}$ are related to the occurrence of discrete volcanic materials. A significant positive Eu anomaly (Zhu et al., 2015) confirms the occurrence of discrete volcanic materials and its dilution effects on terrigenous components since $7 \mathrm{ka}$. Occurrence of discrete volcanic material is likely related to an intensified Kuroshio Current during the middle-late Holocene, as supported by higher hydrothermal $\mathrm{Hg}$ concentrations in sediments from the middle OT (Lim et al., 2017). A negative correlation between $\mathrm{Mn}$ and Mo $\mathrm{Moxcess}_{\mathrm{s}}$ during the last glaciation and the Holocene and the strong positive correlation between them during the LGM and HS1 (Fig. 5a and b) further corroborate the complex geochemical behaviors of Mn and Mo. A strong positive correlation between $\mathrm{Mo}_{\text {excess }}$ and Mn (Fig. 5b) may be attributed to coprecipitation of Mo by manganese oxyhydroxide under oxygenated conditions. Here, we thus use the Mo/Mn ratio, instead of an excess Mo concentration to reconstruct variations in sedimentary redox conditions in our study area. Overall, the $\mathrm{Mo} / \mathrm{Mn}$ ratio shows a similar downcore pattern to that of Moexcess with higher ratios during the last deglaciation but 
lower ratios during the LGM and HS1. A strong correlation $(r=0.69)$ between $\mathrm{Mo} / \mathrm{Mn}$ ratio and excess $\mathrm{U}$ concentration (excluding Holocene data, due to the contamination with volcanic material; Fig. 5c) further corroborates the integrity of $\mathrm{Mo} / \mathrm{Mn}$ as an indicator of sedimentary oxygenation changes.

Rapidly decreasing $\mathrm{Mo} / \mathrm{Mn}$ ratios indicate a welloxygenated sedimentary environment after $\sim 8 \mathrm{ka}$ (Fig. $4 \mathrm{~h}$ ). Both higher $\mathrm{Mo} / \mathrm{Mn}$ ratios and excess $\mathrm{U}$ concentrations, together with lower Mn concentrations, suggest suboxic depositional conditions during the late deglacial period (15.8$9.5 \mathrm{ka}$ ), whereas lower ratios during the LGM, HS1 and HS2 indicate relatively better-oxygenated sedimentary conditions. A decreasing trend in the $\mathrm{Mo} / \mathrm{Mn}$ ratio and the excess $\mathrm{U}$ concentration from 50 to $25 \mathrm{ka}$ also suggest higher sedimentary oxygen levels.

\section{Discussion}

\subsection{Constraining paleo-redox conditions in the Okinawa Trough}

In general, three different terms, hypoxia, suboxia and anoxia, are widely used to describe the degree of oxygen depletion in the marine environment (Hofmann et al., 2011). Here, we adopt the definition of oxygen thresholds by Bianchi et al. (2012) for oxic ( $>120 \mu \mathrm{mol} \mathrm{kg}-1 \mathrm{O}_{2}$ ), hypoxic $\left(<60-120 \mu \mathrm{mol} \mathrm{kg}^{-1} \mathrm{O}_{2}\right)$ and suboxic $(<2-10 \mu \mathrm{mol} \mathrm{kg}-1$ $\mathrm{O}_{2}$ ) conditions, whereas anoxia is the absence of measurable oxygen.

Proxies associated with RSEs, such as sedimentary Mo concentration (Lyons et al., 2009; Scott et al., 2008) have been used to constrain the degree of oxygenation in seawater. Algeo and Tribovillard (2009) proposed that open-ocean systems with suboxic waters tend to yield $U_{\text {excess }}$ enrichment relative to $\mathrm{Mo}_{\text {excess }}$, resulting in a sediment $(\mathrm{Mo} / \mathrm{U})_{\text {excess }}$ ratio less than that of seawater (7.5-7.9). Under increasingly reducing and occasionally sulfidic conditions, the accumulation of $\mathrm{Mo}_{\text {excess }}$ increases relative to that of $\mathrm{U}_{\text {excess }}$ leading the $(\mathrm{Mo} / \mathrm{U})_{\text {excess }}$ ratio either being equal to or exceeding that of seawater. Furthermore, Scott and Lyons (2012) suggested a non-euxinic condition with the presence of sulfide in pore waters when Mo concentrations range from $>2 \mu \mathrm{g} \mathrm{g}^{-1}$ to $<25 \mu \mathrm{gg}^{-1}$. Given that the northern OT is located in an open-ocean setting, we use these two proxies to evaluate the degree of oxygenation in sediments.

Both the bulk Mo concentration (1.2-9.5 $\mathrm{gg}^{-1}$ ) and excess $(\mathrm{Mo} / \mathrm{U})$ ratio $(0.2-5.7)$ in core $\mathrm{CSH} 1$ suggest that oxygen-depleted conditions have prevailed in the deep water of the northern OT over the last $50 \mathrm{ka}$ (Fig. 4m). However, increased excess Mo concentrations with higher Mo/U ratios during the last termination (18-9 ka) indicate more reducing conditions compared to the Holocene and the last glacial period, though Mo concentrations were less than $25 \mu \mathrm{gg}^{-1}$, a threshold for euxinic deposition proposed by Scott and Lyons (2012).
The relative abundance of benthic foraminifera species that thrive in different oxygen concentrations has also been widely used to reconstruct variations in bottom water ventilation, such as the enhanced abundance of Bulimina aculeata, Uvigerina peregrina and Chilostomella oolina found under oxygen-depleted conditions in the central and southern OT from 18 to $9.2 \mathrm{ka}$ (Jian et al., 1996; Li et al., 2005). An oxygenated bottom water condition is also indicated by abundant benthic foraminifera species Cibicidoides hyalina and Globocassidulina subglobosa after 9.2 ka (Jian et al., 1996; Li et al., 2005) in cores E017 (1826 m water depth) and 255 (1575 $\mathrm{m}$ water depth) and high benthic $\delta^{13} \mathrm{C}$ values (Wahyudi and Minagawa, 1997) in core PN-3 (1058 m water depth) from the middle and southern OT during the postglacial period. The poorly ventilated deep water in the middle and southern OT inferred by benthic foraminiferal assemblages during the last deglaciation correlates with the one in the northern OT referring to our RSEs (Fig. 4). A link thus can be hypothesized between deepwater ventilation and sedimentary oxygenation in the OT. Overall, a combination of our proxy records of RSEs in core CSH1 with other records shows oxygen-rich conditions during the last glaciation and middle and late Holocene (since $8.5 \mathrm{ka}$ ) intervals but oxygenpoor conditions during the last deglaciation.

\subsection{Causes for sedimentary oxygenation variations}

Our observed pattern of RSEs in core CSH1 suggests that drastic changes in sedimentary oxygenation occurred on orbital and millennial timescales over the last glaciation in the OT. In general, four factors can regulate the redox condition in the deep water column and are as follows: (i) $\mathrm{O}_{2}$ solubility, (ii) export productivity and subsequent degradation of organic matter, (iii) vertical mixing and (iv) lateral supply of oxygen through intermediate and deeper water masses (Ivanochko and Pedersen, 2004; Jaccard and Galbraith, 2012). These processes have been invoked in previous studies to explain the deglacial Pacific-wide variations in oxygenation by either one or a combination of these factors (Galbraith and Jaccard, 2015; Moffitt et al., 2015; Praetorius et al., 2015). Our data also suggest drastic variations in sedimentary oxygenation over the last $50 \mathrm{ka}$. However, the mechanisms responsible for sedimentary oxygenation variations in the basin-wide OT and its connection with ventilation of the open North Pacific remain unclear. In order to place our core results in a wider regional context, we compare our proxy records of sedimentary oxygenation ( $\mathrm{U}_{\text {excess }}$ concentration and $\mathrm{Mo} / \mathrm{Mn}$ ratio) and export productivity $\left(\mathrm{CaCO}_{3}\right)$ (Fig. 6ac) with the abundance of Pulleniatina obliquiloculata (an indicator of Kuroshio strength) and sea surface temperature in core CSH1 (Shi et al., 2014), the bulk sedimentary nitrogen isotope (an indicator of denitrification) in core MD01-2404 (Kao et al., 2008), benthic foraminifera $\delta^{13} \mathrm{C}$ (a proxy for ventilation) in cores PN-3 and PC23A (Rella et al., 2012; Wahyudi and Minagawa, 1997) and the abundance of ben- 

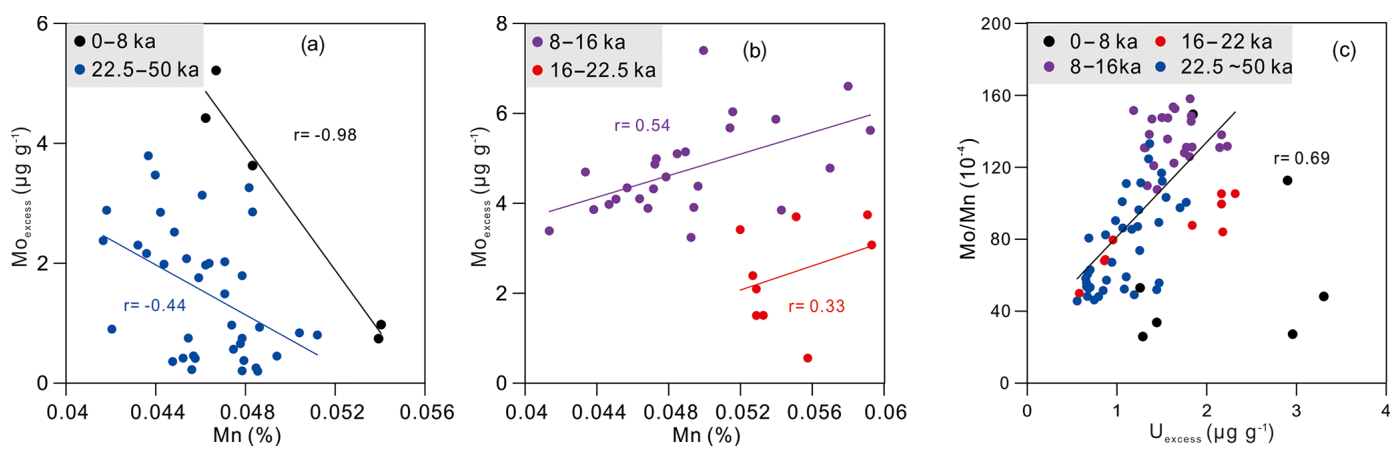

Figure 5. (a, b) Scatter plots of Moexcess vs. Mn concentrations and $U_{\text {excess }}$ concentration vs. Mo/Mn ratio at different time intervals in core CSH1. A varying correlation is present in core CSH1 at different time intervals, which shows their complicated geochemical behaviors. (c) A strong positive correlation between $\mathrm{Mo} / \mathrm{Mn}$ ratio and $\mathrm{U}_{\text {excess }}$ concentration suggests that the Mo/Mn ratio is a reliable proxy to track sedimentary redox conditions in the geological past.

thic foraminifera (an indicator of hypoxia) in core E017 (Li et al., 2005) and ODP Site 1017 (Cannariato and Kennett, 1999) (Fig. 6d-k).

\subsubsection{Effects of regional ocean temperature on deglacial deoxygenation}

Warming ocean temperatures lead to lower oxygen solubility. In the geological past, solubility effects connected to temperature changes in the water column were thought to enhance or even trigger hypoxia (Praetorius et al., 2015). Shi et al. (2014) reported an increase in SST of around $4^{\circ} \mathrm{C}$ (from $\sim 21$ to $\sim 24.6^{\circ} \mathrm{C}$ ) during the last deglaciation in core CSH1 (Fig. 6d). Based on thermal solubility effects, a hypothetical warming of $1{ }^{\circ} \mathrm{C}$ would reduce oxygen concentrations by about $3.5 \mu \mathrm{mol} \mathrm{kg}{ }^{-1}$ at water temperatures around $22^{\circ} \mathrm{C}$ (Brewer and Peltzer, 2016); therefore $\mathrm{a} \sim 4^{\circ} \mathrm{C}$ warming at core CSH1 (Shi et al., 2014) could drive a conservatively estimated drop of $<15 \mu \mathrm{mol} \mathrm{kg}^{-1}$ in oxygen concentration, assuming no large salinity changes. However, given the semiquantitative nature of our data of oxygenation changes, which seemingly exceed an amplitude of $>15 \mu \mathrm{mol} \mathrm{kg}^{-1}$, we suggest that other factors, e.g., local changes in export productivity, regional influences such as vertical mixing due to changes in the Kuroshio Current and far-field effects may have played decisive roles in shaping the oxygenation history of the OT.

\subsubsection{Links between deglacial primary productivity and sedimentary deoxygenation}

Previous studies have suggested the occurrence of high primary productivity in the entire OT during the last deglacial period (Chang et al., 2009; Jian et al., 1996; Kao et al., 2008; Li et al., 2017; Shao et al., 2016; Wahyudi and Minagawa, 1997). Such an increase in export production was due to favorable conditions for phytoplankton blooms, which were likely induced by warm temperatures and maxima in nutri- ent availability, the latter being mainly sourced from an increased discharge of the Changjiang River, erosion of material from the ongoing flooding of the shallow continental shelf in the ECS and upwelling of Kuroshio Intermediate Water (Chang et al., 2009; Li et al., 2017; Shao et al., 2016; Wahyudi and Minagawa, 1997). On the basis of sedimentary reactive phosphorus concentration, Li et al. (2017) concluded that export productivity increased during warm episodes but decreased during cold spells on millennial timescales over the last $91 \mathrm{ka}$ in the OT. Gradually increasing concentrations of $\mathrm{CaCO}_{3}$ in core $\mathrm{CSH} 1$ during the deglaciation (Fig. 6a) and little changes in foraminiferal fragmentation ratios $(\mathrm{Wu}$ et al., 2004), are indicative of high export productivity in the northern OT. Accordingly, our data indicate an increase in export productivity during the last deglaciation, which was previously evidenced by concentrations of reactive phosphorus ( $\mathrm{Li}$ et al., 2017) and $\mathrm{CaCO}_{3}$ (Chang et al., 2009) from the middle OT and thus was a pervasive synchronous phenomenon in the entire study region at the outermost extension of the ECS.

Similar events of high export productivity have been reported in the entire North Pacific due to the increased nutrient supply, high SST, reduced sea ice cover, etc. (Crusius et al., 2004; Dean et al., 1997; Galbraith et al., 2007; Jaccard and Galbraith, 2012; Kohfeld and Chase, 2011). In most of these cases, increased export productivity was thought to be responsible for oxygen depletion in mid-depth waters, due to exceptionally high oxygen consumption. However, the productivity changes during the deglacial interval, very specifically $\mathrm{CaCO}_{3}$, are not fully consistent with the trends of the excess $\mathrm{U}$ and $\mathrm{Mo} / \mathrm{Mn}$ ratio (Fig. $6 \mathrm{~b}$ and c). The sedimentary oxygenation thus cannot be determined by export productivity alone. 


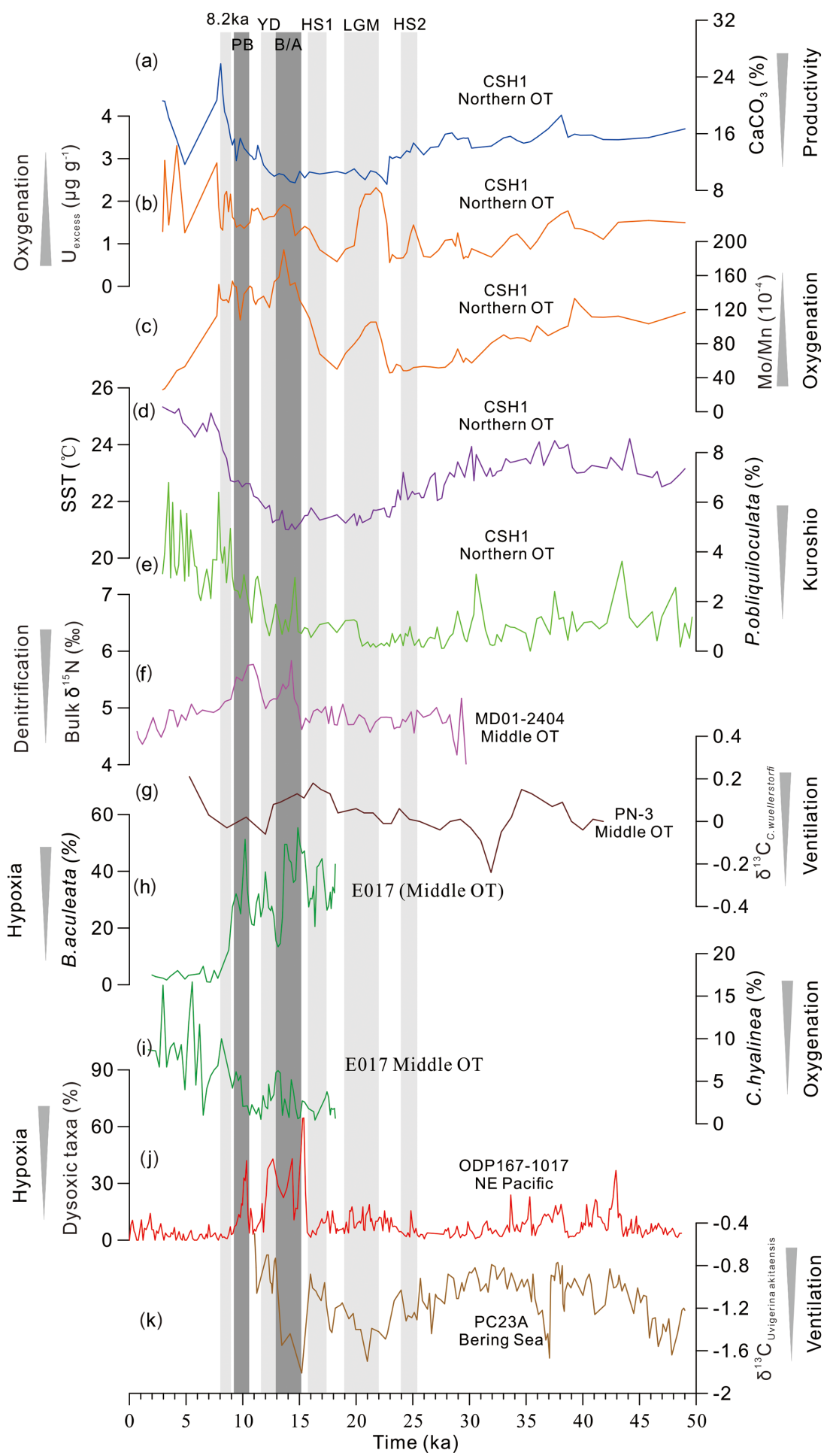

Figure 6. Proxy-related reconstructions of mid-depth sedimentary oxygenation at site CSH1 (this study) compared with oxygenation records from other locations in the North Pacific and published climatic and environmental records from the Okinawa Trough. From top to bottom: (a) $\mathrm{CaCO}_{3}$ concentration, (b) $\mathrm{U}_{\text {excess }}$ concentration, (c) Mo/Mn ratio, (d) sea surface temperature (SST) (Shi et al., 2014), (e) abundance of P. obliquiloculata in core CSH1 (Shi et al., 2014), (f) bulk sedimentary organic matter $\delta^{15} \mathrm{~N}$ in core MD01-2404 (Kao et al., 2008), (g) $\delta^{13} \mathrm{C}$ of epibenthic foraminiferal $C$. wuellerstorfi in core PN-3 (Wahyudi and Minagawa, 1997), (h) relative abundance of $B$. aculeata (hypoxiaindicating species) and (i) $C$. hyalinea (oxygen-rich indicating species) (Li et al., 2005), (j) dysoxic taxa (\%) in core ODP 167-1017 in the northeastern Pacific (Cannariato and Kennett, 1999) and (k) $\delta^{13} \mathrm{C}$ of benthic foraminiferal Uvigerina akitaensis in core PC23A in the Bering Sea (Rella et al., 2012). Light gray and dark gray vertical bars are the same as those in Fig. 4. 


\subsubsection{Effects of the Kuroshio dynamics on sedimentary oxygenation}

The Kuroshio Current, one of the main drivers of vertical mixing, has been identified as the key factor in controlling modern deep ventilation in the OT (Kao et al., 2006). However, the flow path of the Kuroshio in the OT during the glacial interval remains a matter of debate. Planktic foraminiferal assemblages in sediment cores from inside and outside the OT indicated that the Kuroshio migrated to the east side of the Ryukyu Islands during the LGM (Ujiie and Ujiié, 1999). Subsequently, Kao et al. (2006) based on modeling results suggested that the Kuroshio still enters the OT, but the volume transport was reduced by $43 \%$ compared to the present-day transport, and the outlet of Kuroshio switches from the Tokara Strait to the Kerama Gap at -80 and $-135 \mathrm{~m}$ lowered sea level. Combined with sea surface temperature (SST) records and ocean model results, Lee et al. (2013) argued that there was little effect of deglacial sealevel change on the path of the Kuroshio, which still exited the OT from the Tokara Strait during the glacial period. Because the main stream of the Kuroshio Current is at a water depth of $\sim 150 \mathrm{~m}$, the SST records are insufficient to decipher past changes in the Kuroshio (Ujiié et al., 2016). On the other hand, low abundances of $P$. obliquiloculata in core CSH1 in the northern OT (Fig. 6e) indicate that the main flow path of the Kuroshio migrated to the east side of the Ryukyu Island (Shi et al., 2014). Such a flow change would have been caused by the proposed block of the Ryukyu-Taiwan land bridge by low sea level (Ujiié and Ujiié, 1999) and an overall reduced Kuroshio intensity (Kao et al., 2006), effectively suppressing the effect of the Kuroshio on deep ventilation in the OT. Our RSEs data show that oxygenated sedimentary conditions were dominant in the northern OT throughout the last glacial period (Fig. 6b and c). The Kuroshio thus likely had a weak or even no effect on the renewal of oxygen to the sedimentary environment during the last glacial period. More recently, a lower hydrothermal total $\mathrm{Hg}$ concentration during $20-9.6 \mathrm{ka}$, associated with reduced intensity and/or variation in flow path of $\mathrm{KC}$, relative to that of Holocene recorded in core KX12-3 (1423 water depth) (Lim et al., 2017), further validates our inference.

On the other hand, the gradually increased alkenonederived SST and abundance of P.obliquiloculata (Fig. 6d and e) from $15 \mathrm{ka}$ onwards indicate an intensified Kuroshio Current. At present, mooring and float observations revealed that the $\mathrm{KC}$ penetrates to the $1200 \mathrm{~m}$ isobath in the East China Sea (Andres et al., 2015). However, the effect of Kuroshio on sedimentary oxygenation was likely very limited during the glacial period and only gradually increasing throughout the last glacial termination. Therefore, while its effect on our observed deglacial variation in oxygenation may provide a slowly changing background condition in vertical mixing effects on the sedimentary oxygenation in the OT, it cannot account for the first-order, rapid-oxygenation changes, including indications of millennial-scale variations, that we observe between 18 and $9 \mathrm{ka}$.

Better-oxygenated sedimentary conditions since $8.5 \mathrm{ka}$ coincided with an intensified Kuroshio (Li et al., 2005; Shi et al., 2014), as indicated by rapidly increased SST and P. obliquiloculata abundance in core CSH1 (Fig. 6d and e) and $C$. hyalinea abundance in core E017 (Fig. 6i). Reentrance of the Kuroshio into the OT (Shi et al., 2014) with rising eustatic sea level likely enhanced the vertical mixing and exchange between bottom and surface waters, ventilating the deep water in the OT. Previous comparative studies based on epibenthic $\delta^{13} \mathrm{C}$ values indicated well-ventilated deep water feeding both the inside of the OT and the outside of the Ryukyu Islands during the Holocene (Kubota et al., 2015; Wahyudi and Minagawa, 1997). In summary, the enhanced sedimentary oxygenation regime observed in the OT during the Holocene is mainly related to the intensified Kuroshio, while the effect of the Kuroshio on OT oxygenation was limited before $15 \mathrm{ka}$.

\subsubsection{Effects of GNPIW on sedimentary oxygenation}

Relatively stronger oxygenated Glacial North Pacific Intermediate Water (GNPIW), coined by Matsumoto et al. (2002), has been widely documented in the Bering Sea (Itaki et al., 2012; Kim et al., 2011; Rella et al., 2012), the Okhotsk Sea (Itaki et al., 2008; Okazaki et al., 2014, 2006; Wu et al., 2014), the waters off of east Japan (Shibahara et al., 2007), the eastern North Pacific (Cartapanis et al., 2011; Ohkushi et al., 2013) and the western subarctic Pacific (Keigwin, 1998; Matsumoto et al., 2002). The intensified formation of GNPIW due to additional source region in the Bering Sea was proposed by Ohkushi et al. (2003) and Horikawa et al. (2010). Under such conditions, the invasion of wellventilated GNPIW into the OT through the Kerama Gap would have replenished the water column oxygen in the OT, although the penetration depth of GNPIW remains under debate (Jaccard and Galbraith, 2013; Max et al., 2014; Okazaki et al., 2010; Rae et al., 2014). Both a gradual decrease in the excess $\mathrm{U}$ concentration and an increase in the $\mathrm{Mo} / \mathrm{Mn}$ ratio during the last glacial period $(25-50 \mathrm{ka})$ validate such an inference, suggesting pronounced effects of an intensified NPIW formation in the OT.

During HS1, a stronger formation of GNPIW was supported by proxy studies and numerical simulations. For example, on the basis of paired benthic-planktic (B-P) ${ }^{14} \mathrm{C}$ data, enhanced penetration of the NPIW into a much deeper water depth during HS1 relative to the Holocene has been revealed in several studies (Max et al., 2014; Okazaki et al., 2010; Sagawa and Ikehara, 2008) and was also simulated by several models (Chikamoto et al., 2012; Gong et al., 2019; Okazaki et al., 2010). On the other hand, increased intermediate-water temperature in the subtropical Pacific recorded in core GH08-2004 (1166 m water depth) (Kubota et al., 2015) and young deep water observed in the 
northern South China Sea during HS1 (Wan and Jian, 2014) along the downstream region of the NPIW are also related to an intensified NPIW formation. Furthermore, the pathway of GNPIW from numerical model simulations (Zheng et al., 2016) was similar to modern observations (You, 2003). Thus, all of this evidence implies a persistent cause-andeffect relation between GNPIW ventilation, the intermediate and deep water oxygen concentration in the OT, and sediment redox state during HS1. In addition, our RSEs data also suggested a similarly enhanced ventilation in HS2 (Fig. 6b and c) that is also attributed to intensified GNPIW formation.

Hypoxic conditions during the B/A have been also widely observed in the mid- and high-latitude North Pacific (Jaccard and Galbraith, 2012; Praetorius et al., 2015). Our data of the excess $\mathrm{U}$ concentration and $\mathrm{Mo} / \mathrm{Mn}$ ratio recorded in core CSH1 (Fig. 6b and c), together with enhanced denitrification and $B$. aculeata abundance (Fig. $6 \mathrm{f}$ and $\mathrm{h}$ ), further reveal the expansion of oxygen-depletion at mid-depth waters down to the subtropical NW Pacific during the late deglacial period. Based on high relative abundances of radiolarian species, indicators of upper intermediate-water ventilation in core PC23A, Itaki et al. (2012) suggested that a presence of wellventilated waters was limited to the upper intermediate layer (200-500 m) in the Bering Sea during warm periods, such as the B/A and Preboreal. Higher B-P foraminiferal ${ }^{14} \mathrm{C}$ ages, together with increased temperature and salinity at intermediate waters recorded in core GH02-1030 (off east Japan) supported a weakened formation of the NPIW during the B/A (Sagawa and Ikehara, 2008). These lines of evidence indicate that the boundary between GNPIW and North Pacific Deep Water shoaled during the B/A, in comparison to HS1. Based on a comparison of two benthic foraminiferal oxygen and carbon isotope records from off northern Japan and the southern Ryukyu Island, Kubota et al. (2015) found a stronger influence of Pacific Deep Water on intermediatewater temperature and ventilation at their southern compared their northern locations, though both sites are located at similar water depths (1166 and $1212 \mathrm{~m}$ for cores GH08-2004 and GH02-1030, respectively). A higher excess U concentration and low Mo/Mn ratio in our core $\mathrm{CSH} 1$ during the $\mathrm{B} / \mathrm{A}$ and Preboreal suggest reduced sedimentary oxygenation, consistent with reduced ventilation of GNPIW, contributing to the subsurface water deoxygenation in the OT.

During the YD, both the Mo/Mn ratio and excess U show a slightly decreased oxygen condition in the northern OT. By contrast, benthic foraminiferal $\delta^{18} \mathrm{O}$ and $\delta^{13} \mathrm{C}$ values in a sediment core collected from the Oyashio region suggested a strengthened formation and ventilation of GNPIW during the YD (Ohkushi et al., 2016). This pattern possibly indicates a time-dependent, varying contribution of distal GNPIW to the deglacial OT oxygenation history, and we presume a more pronounced contribution of organic matter degradation due to high export productivity during this period, as suggested by increasing the $\mathrm{CaCO}_{3}$ content.

\subsection{Subtropical North Pacific ventilation links to North Atlantic climate}

One of the characteristic climate features in the Northern Hemisphere, in particular the North Atlantic is millennialscale oscillation during glacial and deglacial periods. These abrupt climatic events have been widely thought to be closely related to the varying strength of the Atlantic Meridional Overturning Circulation (AMOC) (Lynch-Stieglitz, 2017). One of dynamic proxies of ocean circulation, ${ }^{231} \mathrm{~Pa} /{ }^{230} \mathrm{Th}$ reveals that severe weakening of the AMOC only existed during Heinrich stadials due to increased freshwater discharges into the North Atlantic (Böhm et al., 2015; McManus et al., 2004). On the other hand, several mechanisms, such as a sudden termination of freshwater input (Liu et al., 2009), an increase in atmospheric $\mathrm{CO}_{2}$ concentration (Zhang et al., 2017), an enhanced advection of salt (Barker et al., 2010) and changes in background climate (Knorr and Lohmann, 2007), were proposed to explain the reinvigoration of the AMOC during the B/A.

Our RSEs data in the Northern OT and endobenthic $\delta^{13} \mathrm{C}$ in the Bering Sea (Fig. 7a-c) both show a substantial millennial variability in intermediate-water ventilation in the subtropical North Pacific. Notably, enhanced ventilation during HS1 and HS2 and oxygen-poor conditions during the B/A, respectively, correspond to the collapse and resumption of the AMOC (Fig. 7d). Such an out-of-phase millennial-scale pattern is consistent with the results of various modeling simulations (Chikamoto et al., 2012; Menviel et al., 2014; Okazaki et al., 2010; Saenko et al., 2004), although these models had different boundary conditions and causes for the observed effects in GNPIW formation and ventilation ages derived from B-P ${ }^{14} \mathrm{C}$ (Freeman et al., 2015; Max et al., 2014; Okazaki et al., 2012). These lines of evidence confirm a persistent link between the ventilation of the North Pacific and North Atlantic climate (Lohmann et al., 2019). Such links have also been corroborated by proxy data and modeling experiment between the AMOC and East Asian monsoon during the $8.2 \mathrm{ka}$ event (Liu et al., 2013), the Holocene (Wang et al., 2005) and 34-60 ka (Sun et al., 2012). The mechanism linking East Asia with the North Atlantic has been attributed to an atmospheric teleconnection, such as the position and strength of the westerly jet and Mongolia-Siberian High (Porter and Zhisheng, 1995). However, the mechanism behind such an out-of-phase pattern between the ventilation in the subtropical North Pacific and the North Atlantic deep water formation remains unclear.

Increased NPIW formation during HS1 may have been caused by enhanced salinity-driven vertical mixing through higher meridional water mass transport from the subtropical Pacific. Previous studies have proposed that intermediatewater formation in the North Pacific hinged on a basin-wide increase in sea surface salinity driven by changes in strength of the summer EAM and the moisture transport from the Atlantic to the Pacific (Emile-Geay et al., 2003). Several mod- 

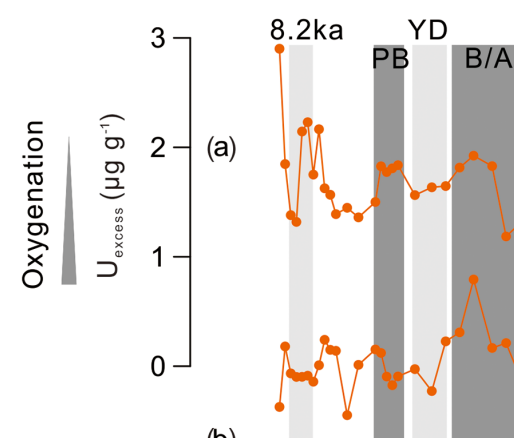

HS1

LGM

HS2

(b)

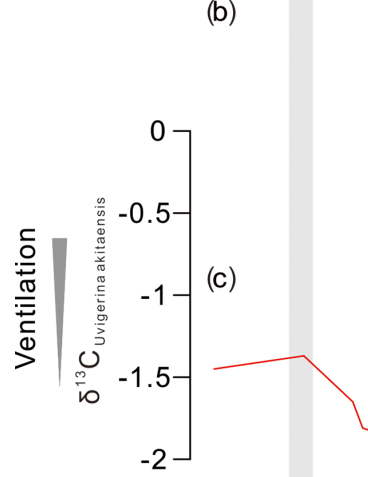

(d)

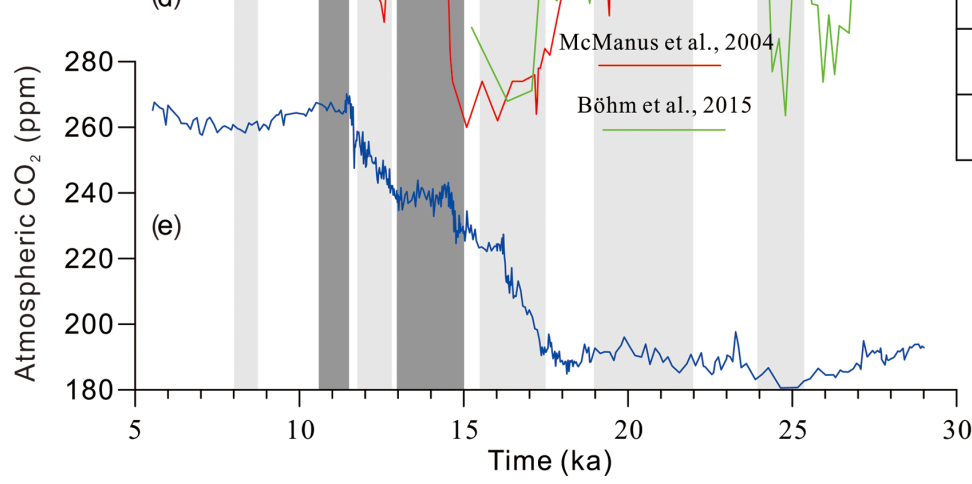

Figure 7. Proxy records favoring the existence of out-of-phase connections between the subtropical North Pacific and North Atlantic during the last deglaciation and enhanced carbon storage at mid-depth waters. (a) $\mathrm{U}_{\text {excess }}$ concentration in core CSH1; (b) Mo/Mn ratio in core CSH1; (c) benthic $\delta^{13} \mathrm{C}$ record in core PC-23A in the Bering Sea (Rella et al., 2012); (d) indicator of the strength of Atlantic Meridional Ocean Circulation $\left({ }^{231} \mathrm{~Pa} /{ }^{230} \mathrm{Th}\right.$ ) (Böhm et al., 2015; McManus et al., 2004); (e) atmospheric $\mathrm{CO}_{2}$ concentration (Marcott et al., 2014). Light gray and dark gray vertical bars are the same as those in Fig. 4.

eling studies found that freshwater forcing in the North Atlantic could cause a widespread surface salinification in the subtropical Pacific Ocean (Menviel et al., 2014; Okazaki et al., 2010; Saenko et al., 2004). This idea has been tested by proxy data (Rodríguez-Sanz et al., 2013; Sagawa and Ikehara, 2008), which indicated a weakened summer EAM and reduced transport of moisture from Atlantic to Pacific through the Isthmus of Panama owing to the southward displacement of the Intertropical Convergence Zone caused by a weakening of the AMOC. Along with this process, as predicted through a general circulation modeling, a strengthened Pacific Meridional Overturning Circulation would have transported more warm and salty subtropical water into the high-latitude North Pacific (Okazaki et al., 2010). In accordance with comprehensive $\mathrm{Mg} / \mathrm{Ca}$ ratio-based salinity reconstructions, however, Riethdorf et al. (2013) found no clear evidence for such higher-salinity patterns in the subarctic northwest Pacific during HS1.

On the other hand, a weakened AMOC would deepen the wintertime Aleutian Low based on modern observation (Okumura et al., 2009), which is closely related to the sea ice formation in the marginal seas of the subarctic Pacific (Cavalieri and Parkinson, 1987). Once stronger Aleutian Low, intense brine rejection due to sea ice expansion, would have enhanced the NPIW formation. Recently modeling-derived evidence confirmed that enhanced sea ice coverage occurred in 
the southern Okhotsk Sea and off the east Kamchatka Peninsula during HS1 (Gong et al., 2019). In addition, stronger advection of low-salinity water via the Alaskan Stream to the subarctic NW Pacific was probably enhanced during HS1, related to a shift in the Aleutian Low pressure system over the North Pacific, which could also increase sea ice formation, brine rejection and thereafter intermediate-water ventilation (Riethdorf et al., 2013).

During the late deglaciation, ameliorating global climate conditions, such as a warming Northern Hemisphere and a strengthened East Asian summer monsoon, are a result of changes in insolation forcing, greenhouse gases concentrations and variable strengths of the AMOC (Clark et al., 2012; Liu et al., 2009). During the B/A, a decrease in sea ice extent and duration was indicated by combined reconstructions of SST and mixed layer temperatures from the subarctic Pacific (Riethdorf et al., 2013). At that time, the rising eustatic sea level (Spratt and Lisiecki, 2016) would have supported the intrusion of the Alaska Stream into the Bering Sea by deepening and opening glacially closed straits of the Aleutian Islands chain, while reducing the advection of the Alaska Stream to the subarctic Pacific Gyre (Riethdorf et al., 2013). In this scenario, saltier and more stratified surface water conditions would have inhibited brine rejection and subsequent formation and ventilation of the NPIW (Lam et al., 2013), leading to a reorganization of the Pacific water mass, closely coupled to the collapse and resumption modes of the AMOC during these two intervals.

\subsection{Increased storage of $\mathrm{CO}_{2}$ at mid-depth water in the North Pacific at the B/A}

One of the striking features of RSEs data is the presence of higher $\mathrm{Mo} / \mathrm{Mn}$ ratios and excess $\mathrm{U}$ concentrations across the $\mathrm{B} / \mathrm{A}$, supporting an expansion of the oxygen minimum zone in the North Pacific (Galbraith and Jaccard, 2015; Jaccard and Galbraith, 2012; Moffitt et al., 2015) and coinciding with the termination of atmospheric $\mathrm{CO}_{2}$ concentration rise (Marcott et al., 2014) (Fig. 7e). As described above, it can be related to the upwelling of nutrient- and $\mathrm{CO}_{2}$-rich Pacific Deep Water due to resumption of the AMOC and enhanced export production. Notably, boron isotope data measured on surface-dwelling foraminifera in core MD01-2416 situated in the western subarctic North Pacific did reveal a decrease in near-surface $\mathrm{pH}$ and an increase in $\mathrm{pCO}_{2}$ at the onset of $\mathrm{B} / \mathrm{A}$ (Gray et al., 2018), indicating that the subarctic North Pacific was a source of the relatively high atmospheric $\mathrm{CO}_{2}$ concentration at that time. Here we cannot conclude that the same processes could have occurred in the subtropical North $\mathrm{Pa}-$ cific due to the lack of well-known drivers to draw out of the old carbon from the deep sea into the atmosphere. In combination with published records from the North Pacific (Addison et al., 2012; Cartapanis et al., 2011; Crusius et al., 2004; Galbraith et al., 2007; Lembke-Jene et al., 2017; Shibahara et al., 2007), an expansion of the oxygen-depleted zone dur- ing the $\mathrm{B} / \mathrm{A}$ suggests an increase in respired carbon storage at mid-depth waters of the North Pacific, which likely stalls the rise of atmospheric $\mathrm{CO}_{2}$. Our results support the findings by Galbraith et al. (2007). Given the sizable volume of the North Pacific, potentially, in the past the respired carbon could have been emitted to the atmosphere in stages, which would have brought the planet out of the last ice age (Jaccard and Galbraith, 2018).

\section{Conclusions}

Our geochemical results of sediment core CSH1 revealed substantial changes in intermediate water redox conditions in the northern Okinawa Trough over the last $50 \mathrm{ka}$ on orbital and millennial timescales. Enhanced sedimentary oxygenation mainly occurred during cold intervals, such as the last glacial period, Heinrich stadials 1 and 2, and during the middle and late Holocene, while diminished sedimentary oxygenation prevailed during the Bölling-Alleröd and Preboreal. The sedimentary oxygenation variability presented here provides key evidence for the substantial impact of ventilation of the NPIW on the sedimentary oxygenation in the subtropical North Pacific and shows an out-of-phase pattern with North Atlantic climate during the last deglaciation. The linkage is attributable to the disruption of the NPIW formation caused by climate changes in the North Atlantic, which are transferred to the North Pacific via atmospheric and oceanic teleconnections. We also suggest an expansion of the oxygendepleted zone and accumulation of respired carbon at the mid-depth waters from previously reported subarctic locations into the western subtropical North Pacific during the $\mathrm{B} / \mathrm{A}$, coinciding with the termination of the atmospheric $\mathrm{CO}_{2}$ rise. A step-wise injection of such respired carbon into the atmosphere would be helpful to maintain high atmospheric $\mathrm{CO}_{2}$ levels during the deglaciation and bring the planet out of the last ice age.

Data availability. All raw data are available to all interested researchers upon request (zoujianjun@ fio.org.cn).

Author contributions. JZ and XS conceived the study. AZ performed geochemical analyses of bulk sediments. JZ, XS, SK and XG led the write-up of the paper. All other authors provided comments on the manuscript and contributed to the final version of the paper.

Competing interests. The authors declare that they have no conflict of interest.

Acknowledgements. Jianjun Zou and Xuefa Shi acknowledge financial support from the National Program on Global Change and 
Air Sea Interaction sponsored by the Ministry of Natural Resources of China, the National Natural Science Foundation of China, the Basic Scientific Fund for National Public Research Institutes of China, International Cooperative Projects in Polar Study of Chinese Arctic and Antarctic Administration and Taishan Scholars Program of Shandong. This study is a contribution to the bilateral Chinese-German cooperation project "Sino-German Pacific-Arctic Ocean Experiment (SIGEPAX)". Xun Gong, Lester Lembke-Jene, Gerrit Lohmann, and Ralf Tiedemann thank the bilateral ChineseGerman Cooperation Project "The North Pacific in Warming Climates (NOPAWAC)". Lester Lembke-Jene and Ralf Tiedemann acknowledge financial support through the national Helmholtz Association REKLIM Initiative. We would like to thank the anonymous reviewers, who helped to improve the quality of this paper.

Financial support. This research has been supported by the National Program on Global Change and Air-Sea Interaction (grant no. GASI-GEOGE-04), the National Natural Science Foundation of China (grant nos. 41876065, 41476056, 41420104005, 41206059 and U1606401), the Basic Scientific Fund for National Public Research Institutes of China (grant no. 2016Q09), the International Cooperative Projects in Polar Study of Chinese Arctic and Antarctic Administration (grant no. 201613), the Taishan Scholars Program of Shandong (Xuefa Shi), and the Chinese-German cooperation projects (funding through BMBF) SIGEPAX (grant no. 03F0704A) and NOPAWAC (grant no. 03F0785A) and the national Helmholtz Association REKLIM Initiative.

Review statement. This paper was edited by Bjørg Risebrobakken and reviewed by two anonymous referees.

\section{References}

Addison, J. A., Finney, B. P., Dean, W. E., Davies, M. H., Mix, A. C., Stoner, J. S., and Jaeger, J. M.: Productivity and sedimentary $\delta^{15} \mathrm{~N}$ variability for the last 17,000 years along the northern Gulf of Alaska continental slope, Paleoceanography, 27, PA1206, https://doi.org/1210.1029/2011PA002161, 2012.

Algeo, T. J.: Can marine anoxic events draw down the trace element inventory of seawater?, Geology, 32, 1057-1060, 2004.

Algeo, T. J. and Lyons, T. W.: Mo-total organic carbon covariation in modern anoxic marine environments: Implications for analysis of paleoredox and paleohydrographic conditions, Paleoceanography, 21, PA1016, https://doi.org/1010.1029/2004pa001112, 2006.

Algeo, T. J. and Tribovillard, N.: Environmental analysis of paleoceanographic systems based on molybdenum-uranium covariation, Chem. Geol., 268, 211-225, 2009.

Andres, M., Jan, S., Sanford, T. B., Mensah, V., Centurioni, L. R., and Book, J. W.: Mean structure and variability of the Kuroshio from northeastern Taiwan to southwestern Japan, Oceanography, 26, 84-95, 2015.

Barker, S., Knorr, G., Vautravers, M. J., Diz, P., and Skinner, L. C.: Extreme deepening of the Atlantic overturning circulation during deglaciation, Nat. Geosci., 3, 567-571, 2010.
Beny, F., Toucanne, S., Skonieczny, C., Bayon, G., and Ziegler, M.: Geochemical provenance of sediments from the northern East China Sea document a gradual migration of the Asian Monsoon belt over the past 400,000 years, Quaternary Sci. Rev., 190, 161175, 2018.

Bianchi, D., Dunne, J. P., Sarmiento, J. L., and Galbraith, E. D.: Data-based estimates of suboxia, denitrification, and $\mathrm{N}_{2} \mathrm{O}$ production in the ocean and their sensitivities to dissolved $\mathrm{O}_{2}$, Global Biogeochem. Cy., 26, GB2009, https://doi.org/10.1029/2011gb004209, 2012.

Böhm, E., Lippold, J., Gutjahr, M., Frank, M., Blaser, P., Antz, B., Fohlmeister, J., Frank, N., Andersen, M. B., and Deininger, M.: Strong and deep Atlantic meridional overturning circulation during the last glacial cycle, Nature, 517, 73-76, 2015.

Brewer, P. G. and Peltzer, E. T.: Ocean chemistry, ocean warming, and emerging hypoxia: Commentary, J. Geophys. Res.-Oceans, 121, 3659-3667, 2016.

Burdige, D. J.: The biogeochemistry of manganese and iron reduction in marine sediments, Earth-Sci. Rev., 35, 249-284, 1993.

Cannariato, K. G. and Kennett, J. P.: Climatically related millennialscale fluctuations in strength of California margin oxygenminimum zone during the past 60 k.y., Geology, 27, 975-978, 1999.

Cartapanis, O., Tachikawa, K., and Bard, E.: Northeastern Pacific oxygen minimum zone variability over the past $70 \mathrm{kyr}$ : Impact of biological production and oceanic ventilation, Paleoceanography, 26, PA4208, https://doi.org/10.1029/2011PA002126, 2011.

Cavalieri, D. J. and Parkinson, C. L.: On the relationship between atmospheric circulation and the fluctuations in the sea ice extents of the bering and okhotsk seas, J. Geophys. Res., 92, 7141-7162, 1987.

Chang, A. S., Pedersen, T. F., and Hendy, I. L.: Effects of productivity, glaciation, and ventilation on late Quaternary sedimentary redox and trace element accumulation on the Vancouver Island margin, western Canada, Paleoceanography, 29, 730-746, https://doi.org/10.1002/2013PA002581, 2014.

Chang, Y.-P., Chen, M.-T., Yokoyama, Y., Matsuzaki, H., Thompson, W. G., Kao, S.-J., and Kawahata, H.: Monsoon hydrography and productivity changes in the East China Sea during the past 100,000 years: Okinawa Trough evidence (MD012404), Paleoceanography, 24, PA3208, https://doi.org/10.1029/2007PA001577, 2009.

Chen, J., Zhang, D., Zhang, W., and Li, T.: The paleoclimatic change since the last galciation in the north of Okinawa Trough based on the spore-pollen records, Acta Oceanol. Sin., 28, 85-91, 2006 (in Chinese with English Abstract).

Cheng, H., Edwards, R. L., Sinha, A., Spötl, C., Yi, L., Chen, S., Kelly, M., Kathayat, G., Wang, X., Li, X., Kong, X., Wang, Y., Ning, Y., and Zhang, H.: The Asian monsoon over the past 640,000 years and ice age terminations, Nature, 534, 640-646, 2016.

Cheng, H., Edwards, R. L., Southon, J., Matsumoto, K., Feinberg, J. M., Sinha, A., Zhou, W., Li, H., Li, X., Xu, Y., Chen, S., Tan, M., Wang, Q., Wang, Y., and Ning, Y.: Atmospheric ${ }^{14} \mathrm{C} /{ }^{12} \mathrm{C}$ changes during the last glacial period from Hulu Cave, Science, 362, 1293-1297, 2018.

Chikamoto, M. O., Menviel, L., Abe-Ouchi, A., Ohgaito, R., Timmermann, A., Okazaki, Y., Harada, N., Oka, A., and Mouchet, A.: Variability in North Pacific intermediate and deep water ven- 
tilation during Heinrich events in two coupled climate models, Deep-Sea Res. Pt. II, 61-64, 114-126, 2012.

Clark, P. U., Shakun, J. D., Baker, P. A., Bartlein, P. J., Brewer, S., Brook, E., Carlson, A. E., Cheng, H., Kaufman, D. S., Liu, Z., Marchitto, T. M., Mix, A. C., Morrill, C., Otto-Bliesner, B. L., Pahnke, K., Russell, J. M., Whitlock, C., Adkins, J. F., Blois, J. L., Clark, J., Colman, S. M., Curry, W. B., Flower, B. P., He, F., Johnson, T. C., Lynch-Stieglitz, J., Markgraf, V., McManus, J., Mitrovica, J. X., Moreno, P. I., and Williams, J. W.: Global climate evolution during the last deglaciation, P. Natl. Acad. Sci. USA, 109, E1134-E1142, 2012.

Clemens, S. C., Holbourn, A., Kubota, Y., Lee, K. E., Liu, Z., Chen, G., Nelson, A., and Fox-Kemper, B.: Precession-band variance missing from East Asian monsoon runoff, Nat. Commun., 9, 3364, https://doi.org/10.1038/s41467-41018-0581441460, 2018.

Crusius, J., Calvert, S., Pedersen, T., and Sage, D.: Rhenium and molybdenum enrichments in sediments as indicators of oxic, suboxic and sulfidic conditions of deposition, Earth Planet. Sc. Lett., 145, 65-78, 1996.

Crusius, J., Pedersen, T. F., Kienast, S., Keigwin, L., and Labeyrie, L.: Influence of northwest Pacific productivity on North Pacific Intermediate Water oxygen concentrations during the BöilingAlleröd interval (14.7-12.9 ka), Geology, 32, 633-636, 2004.

Dahl, T. W., Anbar, A. D., Gordon, G. W., Rosing, M. T., Frei, R., and Canfield, D. E.: The behavior of molybdenum and its isotopes across the chemocline and in the sediments of sulfidic Lake Cadagno, Switzerland, Geochim. Cosmochim. Ac., 74, 144-163, 2010.

Dean, W. E., Gardner, J. V., and Piper, D. Z.: Inorganic geochemical indicators of glacial-interglacial changes in productivity and anoxia on the California continental margin, Geochim. Cosmochim. Ac., 61, 4507-4518, 1997.

Delcroix, T. and Murtugudde, R.: Sea surface salinity changes in the East China Sea during 1997-2001: Influence of the Yangtze River, J. Geophys. Res., 107, 8008, https://doi.org/:10.1029/2001JC000893, 2002.

Dou, Y., Yang, S., Li, C., Shi, X., Liu, J., and Bi, L.: Deepwater redox changes in the southern Okinawa Trough since the last glacial maximum, Prog. Oceanogr., 135, 77-90, 2015.

Emile-Geay, J., Cane, M. A., Naik, N., Seager, R., Clement, A. C., and van Geen, A.: Warren revisited: Atmospheric freshwater fluxes and "Why is no deep water formed in the North Pacific", J. Geophys. Res., 108, 3178, https://doi.org/10.1029/2001JC001058, 2003.

Freeman, E., Skinner, L. C., Tisserand, A., Dokken, T., Timmermann, A., Menviel, L., and Friedrich, T.: An Atlantic-Pacific ventilation seesaw across the last deglaciation, Earth Planet. Sc. Lett., 424, 237-244, 2015.

Galbraith, E. D. and Jaccard, S. L.: Deglacial weakening of the oceanic soft tissue pump: global constraints from sedimentary nitrogen isotopes and oxygenation proxies, Quaternary Sci. Rev., 109, 38-48, 2015.

Galbraith, E. D., Kienast, M., Pedersen, T. F., and Calvert, S. E.: Glacial-interglacial modulation of the marine nitrogen cycle by high-latitude $\mathrm{O}_{2}$ supply to the global thermocline, Paleoceanography, 19, PA4007, https://doi.org/10.1029/2003PA001000, 2004.
Galbraith, E. D., Jaccard, S. L., Pedersen, T. F., Sigman, D. M., Haug, G. H., Cook, M., Southon, J. R., and Francois, R.: Carbon dioxide release from the North Pacific abyss during the last deglaciation, Nature, 449, 890-893, 2007.

Ge, S., Shi, X., Wu, Y., Lee, T., Xiong, Y., and Saito, Y.: Rock magnetic property of gravity core CSH1 from the northern Okinawa Trough and the effect of early diagenesis, Acta Oceanol. Sin., 26, 54-65, 2007.

Gong, X., Lembke-Jene, L., Lohmann, G., Knorr, G., Tiedemann, R., Zou, J. J., and Shi, X. F.: Enhanced North Pacific deep-ocean stratification by stronger intermediate water formation during Heinrich Stadial 1, Nat. Commun., 10, 656, https://doi.org/10.1038/s41467-41019-08606-41462, 2019.

Gray, W. R., Rae, J. W. B., Wills, R. C. J., Shevenell, A. E., Taylor, B., Burke, A., Foster, G. L., and Lear, C. H.: Deglacial upwelling, productivity and $\mathrm{CO}_{2}$ outgassing in the North Pacific Ocean, Nat. Geosci., 11, 340-344, 2018.

Helz, G. R., Miller, C. V., Charnock, J. M., Mosselmans, J. F. W., Pattrick, R. A. D., Garner, C. D., and Vaughan, D. J.: Mechanism of molybdenum removal from the sea and its concentration in black shales: EXAFS evidence, Geochim. Cosmochim. Ac., 60, 3631-3642, 1996.

Hofmann, A. F., Peltzer, E. T., Walz, P. M., and Brewer, P. G.: Hypoxia by degrees: Establishing definitions for a changing ocean, Deep-Sea Res. Pt. I, 58, 1212-1226, 2011.

Hoogakker, B. A. A., Elderfield, H., Schmiedl, G., McCave, I. N., and Rickaby, R. E. M.: Glacial-interglacial changes in bottomwater oxygen content on the Portuguese margin, Nat. Geosci., 8, 40-43, 2015 .

Horikawa, K., Asahara, Y., Yamamoto, K., and Okazaki, Y.: Intermediate water formation in the Bering Sea during glacial periods: Evidence from neodymium isotope ratios, Geology, 38, 435-438, 2010.

Ichikawa, H. and Beardsley, R. C.: The Current System in the Yellow and East China Seas, J. Oceanogr., 58, 77-92, 2002.

Itaki, T., Khim, B. K., and Ikehara, K.: Last glacial-Holocene water structure in the southwestern Okhotsk Sea inferred from radiolarian assemblages, Mar. Micropaleontol., 67, 191-215, 2008.

Itaki, T., Kim, S., Rella, S. F., Uchida, M., Tada, R., and Khim, B. K.: Millennial-scale variations of late Pleistocene radiolarian assemblages in the Bering Sea related to environments in shallow and deep waters, Deep-Sea Res. Pt. II, 61-64, 127-144, 2012.

Ivanochko, T. S. and Pedersen, T. F.: Determining the influences of Late Quaternary ventilation and productivity variations on Santa Barbara Basin sedimentary oxygenation: a multi-proxy approach, Quaternary Sci. Rev., 23, 467-480, 2004.

Jaccard, S. L. and Galbraith, E. D.: Large climate-driven changes of oceanic oxygen concentrations during the last deglaciation, Nat. Geosci., 5, 151-156, 2012.

Jaccard, S. L. and Galbraith, E. D.: Direct ventilation of the North Pacific did not reach the deep ocean during the last deglaciation, Geophys. Res. Lett., 40, 199-203, 2013.

Jaccard, S. L. and Galbraith, E. D.: Push from the Pacific, Nat. Geosci., 11, 299-300, 2018.

Jaccard, S. L., Galbraith, E. D., Sigman, D. M., Haug, G. H., Francois, R., Pedersen, T. F., Dulski, P., and Thierstein, H. R.: Subarctic Pacific evidence for a glacial deepening of the oceanic respired carbon pool, Earth Planet. Sc. Lett., 277, 156-165, 2009. 
Jaccard, S. L., Galbraith, E. D., Martínez-García, A., and Anderson, R. F.: Covariation of deep Southern Ocean oxygenation and atmospheric $\mathrm{CO}_{2}$ through the last ice age, Nature, 530, 207-210, 2016.

Jian, Z. M., Chen, R. H., and Li, B. H.: Deep-sea benthic foraminiferal record of the paleoceanography in the southern Okinawa trough over the last 20000 years, Sci. China Ser. D, 39, 551-560, 1996.

Kao, S. J., Horng, C. S., Hsu, S. C., Wei, K. Y., Chen, J., and Lin, Y. S.: Enhanced deepwater circulation and shift of sedimentary organic matter oxidation pathway in the Okinawa Trough since the Holocene, Geophys. Res. Lett., 32, L15609, https://doi.org/10.11029/12005GL023139, 2005.

Kao, S. J., Wu, C.-R., Hsin, Y.-C., and Dai, M.: Effects of sea level change on the upstream Kuroshio Current through the Okinawa Trough, Geophys. Res. Lett., 33, L16604, https://doi.org/10.11029/12006gl026822, 2006.

Kao, S. J., Liu, K. K., Hsu, S. C., Chang, Y. P., and Dai, M. H.: North Pacific-wide spreading of isotopically heavy nitrogen during the last deglaciation: Evidence from the western Pacific, Biogeosciences, 5, 1641-1650, https://doi.org/10.5194/bg-5-16412008, 2008.

Keigwin, L. D.: Glacial-age hydrography of the far northwest Pacific Ocean, Paleoceanography, 13, 323-339, 1998.

Kim, S., Khim, B. K., Uchida, M., Itaki, T., and Tada, R.: Millennial-scale paleoceanographic events and implication for the intermediate-water ventilation in the northern slope area of the Bering Sea duriing the last 71 kyrs, Global Planet. Change, 79, 89-98, 2011.

Klinkhammer, G. P. and Palmer, M. R.: Uranium in the oceans: Where it goes and why, Geochim. Cosmochim. Ac., 55, 17991806, 1991.

Knorr, G. and Lohmann, G.: Rapid transitions in the Atlantic thermohaline circulation triggered by global warming and meltwater during the last deglaciation, Geochem. Geophy. Geosy., 8, Q12006, https://doi.org/10.1029/2007gc001604, 2007.

Kohfeld, K. E. and Chase, Z.: Controls on deglacial changes in biogenic fluxes in the North Pacific Ocean, Quaternary Sci. Rev., 30, 3350-3363, 2011.

Kubota, Y., Kimoto, K., Tada, R., Oda, H., Yokoyama, Y., and Matsuzaki, H.: Variations of East Asian summer monsoon since the last deglaciation based on $\mathrm{Mg} / \mathrm{Ca}$ and oxygen isotope of planktic foraminifera in the northern East China Sea, Paleoceanography, 25, PA4205, doi10.1029/2009PA001891, 2010.

Kubota, Y., Kimoto, K., Itaki, T., Yokoyama, Y., Miyairi, Y., and Matsuzaki, H.: Bottom water variability in the subtropical northwestern Pacific from $26 \mathrm{kyr} \mathrm{BP}$ to present based on $\mathrm{Mg} / \mathrm{Ca}$ and stable carbon and oxygen isotopes of benthic foraminifera, Clim. Past, 11, 803-824, https://doi.org/10.5194/cp-11-8032015, 2015.

Lam, P. J., Robinson, L. F., Blusztajn, J., Li, C., Cook, M. S., McManus, J. F., and Keigwin, L. D.: Transient stratification as the cause of the North Pacific productivity spike during deglaciation, Nat. Geosci., 6, 622-626, 2013.

Lee, K. E., Lee, H. J., Park, J.-H., Chang, Y.-P., Ikehara, K., Itaki, T., and Kwon, H. K.: Stability of the Kuroshio path with respect to glacial sea level lowering, Geophys. Res. Lett., 40, 392-396, https://doi.org/10.1002/grl.50102, 2013.
Lembke-Jene, L., Tiedemann, R., Nürnberg, D., Kokfelt, U., Kozdon, R., Max, L., Röhl, U., and Gorbarenko, S. A.: Deglacial variability in Okhotsk Sea Intermediate Water ventilation and biogeochemistry: Implications for North Pacific nutrient supply and productivity, Quaternary Sci. Rev., 160, 116-137, 2017.

Li, D., Zheng, L.-W., Jaccard, S. L., Fang, T.-H., Paytan, A., Zheng, X., Chang, Y.-P., and Kao, S.-J.: Millennial-scale ocean dynamics controlled export productivity in the subtropical North Pacific, Geology, 45, 651-654, 2017.

Li, T., Xu, Z., Lim, D., Chang, F., Wan, S., Jung, H., and Choi, J.: $\mathrm{Sr}-\mathrm{Nd}$ isotopic constraints on detrital sediment provenance and paleoenvironmental change in the northern Okinawa Trough during the late Quaternary, Palaeogeogr. Palaeocl., 430, 74-84, 2015.

Li, T. G., Xiang, R., Sun, R. T., and Cao, Q. Y.: Benthic foraminifera and bottom water evolution in the middle-southern Okinawa Trough during the last $18 \mathrm{ka}$, Sci. China Ser. D, 48, 805-814, 2005.

Li, Y. H. and Schoonmaker, J. E.: Chemical Composition and Mineralogy of Marine Sediments, in: Treatise on Geochemistry 2nd edn., edited by: Turekian, K. K., Elsevier, Oxford, 2014.

Lim, D., Kim, J., Xu, Z., Jeong, K., and Jung, H.: New evidence for Kuroshio inflow and deepwater circulation in the Okinawa Trough, East China Sea: Sedimentary mercury variations over the last $20 \mathrm{kyr}$, Paleoceanography, 32, 571-579, 2017.

Liu, Y. H., Henderson, G. M., Hu, C. Y., Mason, A. J., Charnley, N., Johnson, K. R., and Xie, S. C.: Links between the East Asian monsoon and North Atlantic climate during the 8,200 year event, Nat. Geosci., 6, 117-120, 2013.

Liu, Z., Otto-Bliesner, B. L., He, F., Brady, E. C., Tomas, R., Clark, P. U., Carlson, A. E., Lynch-Stieglitz, J., Curry, W., Brook, E., Erickson, D., Jacob, R., Kutzbach, J., and Cheng, J.: Transient Simulation of Last Deglaciation with a New Mechanism for BöllingAlleröd Warming, Science, 325, 310-314, 2009.

Lohmann, G., Lembke-Jene, L., Tiedemann, R., Gong, X., Scholz, P., Zou, J., and Shi, X.: Challenges in the Paleoclimatic Evolution of the Arctic and Subarctic Pacific since the Last Glacial Period-The Sino-German Pacific-Arctic Experiment (SiGePAX), Challenges, 10, 13, https://doi.org/10.3390/challe10010013, 2019.

Lynch-Stieglitz, J.: The Atlantic Meridional Overturning Circulation and Abrupt Climate Change, Annu. Rev. Mar. Sci., 9, 83104, 2017.

Lyons, T. W., Anbar, A. D., Severmann, S., Scott, C., and Gill, B. C.: Tracking Euxinia in the Ancient Ocean: A Multiproxy Perspective and Proterozoic Case Study, Annu. Rev. Earth Planet. Sc., 37, 507-534, 2009.

Machida, H.: The stratigraphy, chronology and distribution of distal marker-tephras in and around Japan, Global Planet. Change, 21, 71-94, 1999.

Maithani, P. B. and Srinivasan, S.: Felsic Volcanic Rocks, a Potential Source of Uranium - An Indian Overview, Energy Proced., 7, 163-168, 2011.

Marcott, S. A., Bauska, T. K., Buizert, C., Steig, E. J., Rosen, J. L., Cuffey, K. M., Fudge, T. J., Severinghaus, J. P., Ahn, J., Kalk, M. L., McConnell, J. R., Sowers, T., Taylor, K. C., White, J. W. C., and Brook, E. J.: Centennial-scale changes in the global carbon cycle during the last deglaciation, Nature, 514, 616-619, 2014. 
Matsumoto, K., Oba, T., Lynch-Stieglitz, J., and Yamamoto, H.: Interior hydrography and circulation of the glacial Pacific Ocean, Quaternary Sci. Rev., 21, 1693-1704, 2002.

Max, L., Lembke-Jene, L., Riethdorf, J.-R., Tiedemann, R., Nürnberg, D., Kühn, H., and Mackensen, A.: Pulses of enhanced North Pacific Intermediate Water ventilation from the Okhotsk Sea and Bering Sea during the last deglaciation, Clim. Past, 10, 591-605, https://doi.org/10.5194/cp-10-591-2014, 2014.

Max, L., Rippert, N., Lembke-Jene, L., Mackensen, A., Nürnberg, D., and Tiedemann, R.: Evidence for enhanced convection of North Pacific Intermediate Water to the low-latitude Pacific under glacial conditions, Paleoceanography, 32, 41-55, 2017.

McManus, J., Berelson, W. M., Klinkhammer, G. P., Hammond, D. E., and Holm, C.: Authigenic uranium: Relationship to oxygen penetration depth and organic carbon rain, Geochim. Cosmochim. Ac., 69, 95-108, 2005.

McManus, J. F., Francois, R., Gherardi, J. M., Keigwin, L. D., and Brown-Leger, S.: Collapse and rapid resumption of Atlantic meridional circulation linked to deglacial climate changes, Nature, 428, 834-837, 2004.

Menviel, L., England, M. H., Meissner, K. J., Mouchet, A., and Yu, J.: Atlantic-Pacific seesaw and its role in outgassing $\mathrm{CO}_{2}$ during Heinrich events, Paleoceanography, 29, 58-70, 2014.

Moffitt, S. E., Moffitt, R. A., Sauthoff, W., Davis, C. V., Hewett, K., and Hill, T. M.: Paleoceanographic Insights on Recent Oxygen Minimum Zone Expansion: Lessons for Modern Oceanography, PLOS ONE, 10, e0115246, https://doi.org/10.1371/journal.pone.0115246, 2015.

Morford, J. L. and Emerson, S.: The geochemistry of redox sensitive trace metals in sediments, Geochim. Cosmochim. Ac., 63, 1735-1750, 1999.

Nakamura, H., Nishina, A., Liu, Z. J., Tanaka, F., Wimbush, M., and Park, J. H.: Intermediate and deep water formation in the Okinawa Trough, J. Geophys. Res.-Oceans, 118, 6881-6893, 2013.

Nameroff, T. J., Balistrieri, L. S., and Murray, J. W.: Suboxic trace metal geochemistry in the Eastern Tropical North Pacific, Geochim. Cosmochim. Ac., 66, 1139-1158, 2002.

Nameroff, T. J., Calvert, S. E., and Murray, J. W.: Glacialinterglacial variability in the eastern tropical North Pacific oxygen minimum zone recorded by redoxsensitive trace metals, Paleoceanography, 19, PA1010, https://doi.org/10.1029/2003PA000912, 2004.

Nishina, A., Nakamura, H., Park, J.-H., Hasegawa, D., Tanaka, Y., Seo, S., and Hibiya, T.: Deep ventilation in the Okinawa Trough induced by Kerama Gap overflow, J. Geophys. Res.-Oceans, 121, 6092-6102, 2016.

Ohkushi, K., Itaki, T., and Nemoto, N.: Last Glacial-Holocene change in intermediate-water ventilation in the Northwestern Pacific, Quaternary Sci. Rev., 22, 1477-1484, 2003.

Ohkushi, K., Kennett, J. P., Zeleski, C. M., Moffitt, S. E., Hill, T. M., Robert, C., Beaufort, L., and Behl, R. J.: Quantified intermediate water oxygenation history of the NE Pacific: A new benthic foraminiferal record from Santa Barbara basin, Paleoceanography, 28, 453-467, 2013.

Ohkushi, K., Hara, N., Ikehara, M., Uchida, M., and Ahagon, N.: Intensification of North Pacific intermediate water ventilation during the Younger Dryas, Geo-Mar. Lett., 36, 353-360, 2016.

Okazaki, Y., Seki, O., Nakatsuka, T., Sakamoto, T., Ikehara, M., and Takahashi, K.: Cycladophora davisiana (Radiolaria) in the
Okhotsk Sea: A key for reconstructing glacial ocean conditions, J. Oceanogr., 62, 639-648, 2006.

Okazaki, Y., Timmermann, A., Menviel, L., Harada, N., Abe-Ouchi, A., Chikamoto, M. O., Mouchet, A., and Asahi, H.: Deepwater Formation in the North Pacific During the Last Glacial Termination, Science, 329, 200-204, 2010.

Okazaki, Y., Sagawa, T., Asahi, H., Horikawa, K., and Onodera, J.: Ventilation changes in the western North Pacific since the last glacial period, Clim. Past, 8, 17-24, https://doi.org/10.5194/cp8-17-2012, 2012.

Okazaki, Y., Kimoto, K., Asahi, H., Sato, M., Nakamura, Y., and Harada, N.: Glacial to deglacial ventilation and productivity changes in the southern Okhotsk Sea, Palaeogeogr. Palaeocl., 395, 53-66, 2014.

Okumura, Y. M., Deser, C., Hu, A., Timmermann, A., and Xie, S.P.: North Pacific Climate Response to Freshwater Forcing in the Subarctic North Atlantic: Oceanic and Atmospheric Pathways, J. Climate, 22, 1424-1445, 2009.

Porter, S. C. and Zhisheng, A.: Correlation between climate events in the North Atlantic and China during the last glaciation, Nature, 375, 305-308, 1995.

Praetorius, S. K., Mix, A. C., Walczak, M. H., Wolhowe, M. D., Addison, J. A., and Prahl, F. G.: North Pacific deglacial hypoxic events linked to abrupt ocean warming, Nature, 527, 362-366, 2015.

Qu, T. and Lukas, R.: The Bifurcation of the North Equatorial Current in the Pacific, J. Phys. Oceanogr., 33, 5-18, 2003.

Rae, J. W. B., Sarnthein, M., Foster, G. L., Ridgwell, A., Grootes, P. M., and Elliott, T.: Deep water formation in the North Pacific and deglacial $\mathrm{CO}_{2}$ rise, Paleoceanography, 29, 645-667, 2014.

Reimer, P. J., Bard, E., Bayliss, A., Beck, J. W., Blackwell, P. G., Bronk Ramsey, C., Buck, C. E., Cheng, H., Edwards, R. L., Friedrich, M., Grootes, P. M., Guilderson, T. P., Haflidason, H., Hajdas, I., Hatté, C., Heaton, T. J., Hoffmann, D. L., Hogg, A. G., Hughen, K. A., Kaiser, K. F., Kromer, B., Manning, S. W., Niu, M., Reimer, R. W., Richards, D. A., Scott, E. M., Southon, J. R., Staff, R. A., Turney, C. S. M., and van der Plicht, J.: IntCal13 and Marine13 Radiocarbon Age Calibration Curves 0-50,000 Years cal BP, Radiocarbon, 55, 1869-1887, 2013.

Rella, S. F., Tada, R., Nagashima, K., Ikehara, M., Itaki, T., Ohkushi, K., Sakamoto, T., Harada, N., and Uchida, M.: Abrupt changes of intermediate water properties on the northeastern slope of the Bering Sea during the last glacial and deglacial period, Paleoceanography, 27, PA3203, https://doi.org/10.1029/2011pa002205, 2012.

Riethdorf, J.-R., Max, L., Nuernberg, D., Lembke-Jene, L., and Tiedemann, R.: Deglacial development of (sub) sea surface temperature and salinity in the subarctic northwest Pacific: Implications for upper-ocean stratification, Paleoceanography, 28, 91104, https://doi.org/10.1002/palo.20014, 2013.

Riethdorf, J.-R., Thibodeau, B., Ikehara, M., Nürnberg, D., Max, L., Tiedemann, R., and Yokoyama, Y.: Surface nitrate utilization in the Bering sea since 180kA BP: Insight from sedimentary nitrogen isotopes, Deep-Sea Res. Pt. II, 125-126, 163-176, 2016.

Rippert, N., Max, L., Mackensen, A., Cacho, I., Povea, P., and Tiedemann, R.: Alternating Influence of Northern Versus Southern-Sourced Water Masses on the Equatorial Pacific Subthermocline During the Past 240 ka, Paleoceanography, 32, 1256-1274, 2017. 
Rodríguez-Sanz, L., Mortyn, P. G., Herguera, J. C., and Zahn, R.: Hydrographic changes in the tropical and extratropical Pacific during the last deglaciation, Paleoceanography, 28, 529-538, 2013.

Rühlemann, C., Müller, P. J., and Schneider, R. R.: Organic Carbon and Carbonate as Paleoproductivity Proxies: Examples from High and Low Productivity Areas of the Tropical Atlantic, in: Use of Proxies in Paleoceanography: Examples from the South Atlantic, edited by: Fischer, G. and Wefer, G., Springer Berlin Heidelberg, Berlin, Heidelberg, 1999.

Saenko, O. A., Schmittner, A., and Weaver, A. J.: The AtlanticPacific seesaw, J. Climate, 17, 2033-2038, 2004.

Sagawa, T. and Ikehara, K.: Intermediate water ventilation change in the subarctic northwest Pacific during the last deglaciation, Geophys. Res. Lett., 35, L24702, https://doi.org/10.1029/2008g1035133, 2008.

Schlitzer, R.: Ocean Data View, available at: http://odv.awi.de (last access: January 2018), 2016.

Scott, C. and Lyons, T. W.: Contrasting molybdenum cycling and isotopic properties in euxinic versus non-euxinic sediments and sedimentary rocks: Refining the paleoproxies, Chem. Geol., 324-325, 19-27, 2012.

Scott, C., Lyons, T. W., Bekker, A., Shen, Y., Poulton, S. W., Chu, X., and Anbar, A. D.: Tracing the stepwise oxygenation of the Proterozoic ocean, Nature, 452, 456-459, 2008.

Shao, H., Yang, S., Cai, F., Li, C., Liang, J., Li, Q., Hyun, S., Kao, S.-J., Dou, Y., Hu, B., Dong, G., and Wang, F.: Sources and burial of organic carbon in the middle Okinawa Trough during late Quaternary paleoenvironmental change, Deep-Sea Res. Pt. I, 118, 46-56, 2016.

Shcherbina, A. Y., Talley, L. D., and Rudnick, D. L.: Direct observations of North Pacific ventilation: Brine rejection in the Okhotsk Sea, Science, 302, 1952-1955, 2003.

Shi, X., Wu, Y., Zou, J., Liu, Y., Ge, S., Zhao, M., Liu, J., Zhu, A., Meng, X., Yao, Z., and Han, Y.: Multiproxy reconstruction for Kuroshio responses to northern hemispheric oceanic climate and the Asian Monsoon since Marine Isotope Stage $5.1(\sim 88 \mathrm{ka})$, Clim. Past, 10, 1735-1750, https://doi.org/10.5194/cp-10-17352014, 2014.

Shibahara, A., Ohkushi, K., Kennett, J. P., and Ikehara, K.: Late Quaternary changes in intermediate water oxygenation and oxygen minimum zone, northern Japan: A benthic foraminiferal perspective, Paleoceanography, 22, PA3213, https://doi.org/10.1029/2005pa001234, 2007.

Shimmield, G. B. and Price, N. B.: The behaviour of molybdenum and manganese during early sediment diagenesis - offshore Baja California, Mexico, Mar. Chem., 19, 261-280, 1986.

Sibuet, J. C., Letouzey, J., Barbier, F., Charvet, J., Foucher, J. P., Hilde, T. W. C., Kimura, M., Chiao, L.-Y., Marsset, B., Muller, C., and Stéphan, J. F.: Back Arc Extension in the Okinawa Trough, J. Geophys. Res., 92, 14041-14063, https://doi.org/10.1029/JB092iB13p14041, 1987.

Sigman, D. M. and Boyle, E. A.: Glacial/interglacial variations in atmospheric carbon dioxide, Nature, 407, 859-869, 2000.

Spratt, R. M. and Lisiecki, L. E.: A Late Pleistocene sea level stack, Clim. Past, 12, 1079-1092, https://doi.org/10.5194/cp-12-10792016, 2016.
Sun, Y., Clemens, S. C., Morrill, C., Lin, X., Wang, X., and An, Z.: Influence of Atlantic meridional overturning circulation on the East Asian winter monsoon, Nat. Geosci., 5, 46-49, 2012.

Sun, Y. B., Oppo, D. W., Xiang, R., Liu, W. G., and Gao, S.: Last deglaciation in the Okinawa Trough: Subtropical northwest Pacific link to Northern Hemisphere and tropical climate, Paleoceanography, 20, PA4005, https://doi.org/10.1029/2004pa001061, 2005.

Sundby, B., Martinez, P., and Gobeil, C.: Comparative geochemistry of cadmium, rhenium, uranium, and molybdenum in continental margin sediments, Geochim. Cosmochim. Ac., 68, 2485-2493, 2004.

Talley, L. D.: Distribution foramtion of North Pacific Intermediate water, J. Phys. Oceanogr., 23, 517-537, 1993.

Talley, L. D.: Hydrographic Atlas of the World Ocean Circulation Experiment (WOCE), in: vol. 2: Pacific Ocean, edited by: Sparrow, M., Chapman, P., and Gould, J., International WOCE Project Office, Southampton, UK, 2007.

Tribovillard, N., Algeo, T. J., Lyons, T., and Riboulleau, A.: Trace metals as paleoredox and paleoproductivity proxies: An update, Chem. Geol., 232, 12-32, 2006.

Ujiié, H. and Ujiié, Y.: Late Quaternary course changes of the Kuroshio Current in the Ryukyu Arc region, northwestern Pacific Ocean, Mar. Micropaleontol., 37, 23-40, 1999.

Ujiié, Y., Ujiié, H., Taira, A., Nakamura, T., and Oguri, K.: Spatial and temporal variability of surface water in the Kuroshio source region, Pacific Ocean, over the past 21,000 years: evidence from planktonic foraminifera, Mar. Micropaleontol., 49, 335-364, 2003.

Ujiié, Y., Asahi, H., Sagawa, T., and Bassinot, F.: Evolution of the North Pacific Subtropical Gyre during the past 190 kyr through the interaction of the Kuroshio Current with the surface and intermediate waters, Paleoceanography, 31, 1498-1513, 2016.

Vorlicek, T. P. and Helz, G. R.: Catalysis by mineral surfaces: Implications for Mo geochemistry in anoxic environments, Geochim. Cosmochim. Ac., 66, 3679-3692, 2002.

Wahyudi and Minagawa, M.: Response of benthic foraminifera to organic carbon accumulation rates in the Okinawa Trough, J. Oceanogr., 53, 411-420, 1997.

Wan, S. and Jian, Z.: Deep water exchanges between the South China Sea and the Pacific since the last glacial period, Paleoceanography, 29, 1162-1178, 2014.

Wang, Y., Cheng, H., Edwards, R. L., He, Y., Kong, X., An, Z., Wu, J., Kelly, M. J., Dykoski, C. A., and Li, X.: The Holocene Asian Monsoon: Links to Solar Changes and North Atlantic Climate, Science, 308, 854-857, 2005.

Wu, Y., Cheng, Z., and Shi, X.: Stratigraphic and carbonate sediment characteristics of Core CSH1 from the northern Okinawa Trough, Advances in Marine Science, 22, 163-169, 2004 (in Chinese with English Abstract).

Wu, Y., Shi, X., Zou, J., Cheng, Z., Wang, K., Ge, S., and Shi, F.: Benthic foraminiferal $\delta 13 \mathrm{C}$ minimum events in the southeastern Okhotsk Sea over the last $180 \mathrm{ka}$, Chinese Sci. Bull., 59, 30663074, 2014.

You, Y. Z.: The pathway and circulation of North Pacific Intermediate Water, Geophys. Res. Lett., 30, 2291, https://doi.org/10.1029/2003gl018561, 2003.

You, Y. Z., Suginohara, N., Fukasawa, M., Yasuda, I., Kaneko, I., Yoritaka, H., and Kawamiya, M.: Roles of the Okhotsk Sea and 
Gulf of Alaska in forming the North Pacific Intermediate Water, J. Geophys. Res., 105, 3253-3280, 2000.

You, Y. Z., Suginohara, N., Fukasawa, M., Yoritaka, H., Mizuno, K., Kashino, Y., and Hartoyo, D.: Transport of North Pacific Intermediate Water across Japanese WOCE sections, J. Geophys. Res., 108, 3196, https://doi.org/10.1029/2002jc001662, 2003.

Yu, H., Liu, Z. X., Berne, S., Jia, G. D., Xiong, Y. Q., Dickens, G. R., Wei, G. J., Shi, X. F., Liu, J. P., and Chen, F. J.: Variations in temperature and salinity of the surface water above the middle Okinawa Trough during the past 37 kyr, Palaeogeogr. Palaeocl., 281, 154-164, 2009.

Zhang, X., Knorr, G., Lohmann, G., and Barker, S.: Abrupt North Atlantic circulation changes in response to gradual $\mathrm{CO}_{2}$ forcing in a glacial climate state, Nat. Geosci., 10, 518-524, 2017.

Zhao, D., Wan, S., Toucanne, S., Clift, P. D., Tada, R., Révillon, S., Kubota, Y., Zheng, X., Yu, Z., Huang, J., Jiang, H., Xu, Z., Shi, X., and Li, A.: Distinct control mechanism of fine-grained sediments from Yellow River and Kyushu supply in the northern Okinawa Trough since the last glacial, Geochem. Geophy. Geosy., 18, 2949-2969, 2017.
Zheng, X., Kao, S., Chen, Z., Menviel, L., Chen, H., Du, Y., Wan, S., Yan, H., Liu, Z., Zheng, L., Wang, S., Li, D., and Zhang, $X .:$ Deepwater circulation variation in the South China Sea since the Last Glacial Maximum, Geophys. Res. Lett., 43, 8590-8599, 2016.

Zheng, Y., Anderson, R., van Geen, A., and Kuwabara, J.: Authigenic molybdenum formation in marine sediments: a link to pore water sulfide in the Santa Barbara Basin, Geochim. Cosmochim. Ac., 64, 4165-4178, 2000.

Zheng, Y., Anderson, R., van Geen, A., and Fleisher, M.: Remobilization of authigenic uranium in marine sediments by bioturbation, Geochim. Cosmochim. Ac., 66, 1759-1772, 2002.

Zhu, A., Shi, X., Zou, J., Wu, Y., Zhang, H., and Bai, Y.: Sediment Provenance and Fluxes in the Northern Okinawa Trough During the last $88 \mathrm{ka}$, Marine Geology \& Quaternary Geology, 35, 1-8, 2015 (in Chinese with English Abstract).

Zou, J., Shi, X., Liu, Y., Liu, J., Selvaraj, K., and Kao, S.-J.: Reconstruction of environmental changes using a multi-proxy approach in the Ulleung Basin (Sea of Japan) over the last $48 \mathrm{ka}$, J. Quaternary Sci., 27, 891-900, 2012. 